Fulvia Skof (Ed.)

Giuseppe Peano between Mathematics

and Logic 
Giuseppe Peano between Mathematics and Logic 


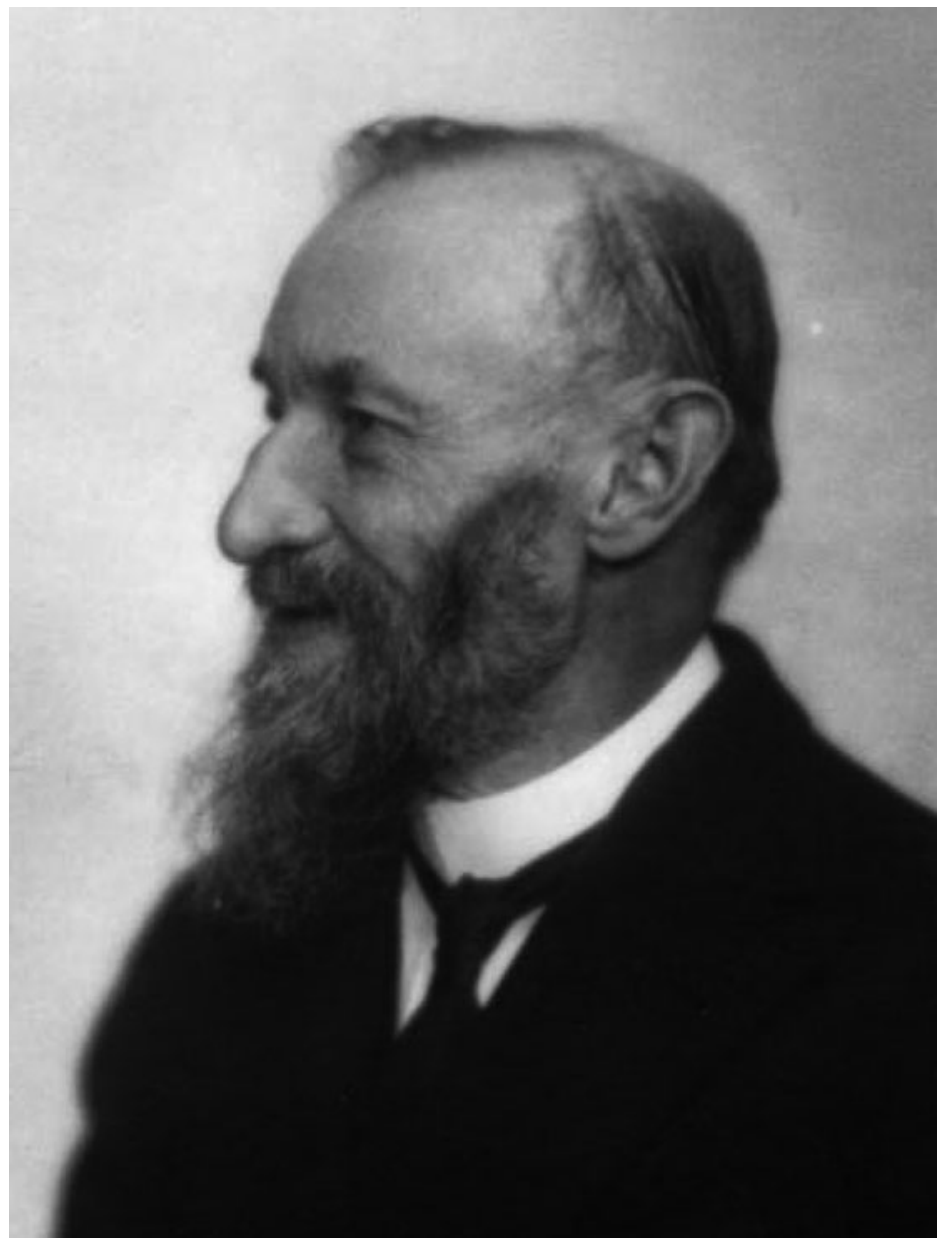

Giuseppe Peano (1858-1932) in 1928 - Department of Mathematics G. Peano, University of Torino 
Fulvia Skof

Editor

\section{Giuseppe Peano between Mathematics and Logic}

Proceeding of the International Conference in honour of Giuseppe Peano on the 150th anniversary of his birth and the centennial of the Formulario Mathematico, Turin (Italy), October 2-3, 2008 
Editor

Fulvia Skof

Department of Mathematics "G. Peano"

University of Torino, Italy

The publication of this book has been made possible by the financial support of the Accademia delle Scienze of Torino, Department of Mathematics of the Torino University and Compagnia di San Paolo.

ISBN 978-88-470-1835-8

e-ISBN 978-88-470-1836-5

DOI $10.1007 / 978-88-470-1836-5$

Springer Milan Dordrecht Heidelberg London New York

Library of Congress Control Number: 2010938967

(C) Springer-Verlag Italia 2011

This work is subject to copyright. All rights are reserved, whether the whole or part of the material is concerned, specifically the rights of translation, reprinting, reuse of illustrations, recitation, broadcasting, reproduction on microfilm or in any other way, and storage in data banks. Duplication of this publication or parts thereof is permitted only under the provisions of the German Copyright Law of September 9, 1965 , in its current version, and permission for use must always be obtained from Springer. Violations are liable to prosecution under the German Copyright Law.

The use of general descriptive names, registered names, trademarks, etc. in this publication does not imply, even in the absence of a specific statement, that such names are exempt from the relevant protective laws and regulations and therefore free for general use.

The publisher and the authors accept no legal responsibility for any damage caused by improper use of the instructions and programs contained in this book and the CD. Although the software has been tested with extreme care, errors in the software cannot be excluded.

Cover design: Simona Colombo, Milano

Typesetting: le-tex publishing services $\mathrm{GmbH}$, Leipzig, Germany

Printing and binding: Grafiche Porpora, Segrate (MI)

Printed on acid-free paper

Springer-Verlag Italia S.r.1, Via Decembrio 28, I-20137 Milano

Springer is part of Springer Science+Business Media (www.springer.com) 


\section{Preface}

Giuseppe Peano was one of the greatest figures in modern mathematics and logic, and without a doubt the most important Italian mathematical logician, esteemed by Bertrand Russell as well as Rudolf Carnap and Kurt Gödel. Born in a small village near Cuneo, in southern Piedmont, in August 1858 - on the eve of Italian unity he studied in Turin, where he would then rapidly advance through the successive levels of his academic career: he received his habilitation in Infinitesimal Calculus in 1884, became a professor at the Military Academy in 1889, entered the University of Torino in 1890 and was a full professor of Infinitesimal Calculus from 1895 to 1931, and was also a full professor of Complementary Mathematics until his death in April 1932. As early as 1891 he was a member of Turin's Accademia delle Scienze, and in 1905 became a member of the Accademia Nazionale dei Lincei as well.

On the occasion of the one hundred fiftieth anniversary of Peano's birth, and a century after the publication of the fifth edition of the Formulario Mathematico, a grandiose attempt to systematise mathematics in symbolic form, the Accademia delle Scienze of Torino and the University of Torino (in particular, the Faculty of Mathematical, Physical and Natural Sciences and the Department of Mathematics), together with the Italian Society for the History of Mathematics, created a committee for the celebration of this dual occasion, the presidency of which was entrusted to Prof. Clara Silvia Roero. Among the many initiatives organised by the committee, one of the most important with respect to science was the international conference entitled "Giuseppe Peano between Mathematics and Logic", which took place on 2-3 October 2008 under the auspices of the President of the Republic and with the sponsorship of the Accademia Nazionale dei Lincei and the Istituto Lombardo Accademia di Scienze, Lettere e Arti. The conference provided an examination of the various aspects of Peano's work, presented by the greatest scholars from Italy and abroad. This present volume contains the papers that developed out of the presentations given during the conference.

The conference was made possible by funding contributed by the Region of Piedmont, the Compagnia di San Paolo and the Cassa di Risparmio di Cuneo, as well as the Accademia delle Scienze of Torino - under the presidency of Angelo Raffaele Meo - which hosted the conference in the "Sala dei Mappamondi". We are most 
grateful to these institutions. Particular thanks go to Prof. Roero, then president of the Italian Society for the History of Mathematics, for her efficient and indefatigable organisational work, and for her valuable collaboration with Prof. Fulvia Skof in collecting and editing the papers that appear here.

Turin, September 2010

Accademia delle Scienze 


\title{
The Formulario between Mathematics and History
}

\author{
Clara Silvia Roero
}

Dal libro di Lebesgue potrà risultare un rigo, o mezza pagina. G. Peano to G. Vitali, 3 April 1905

For almost twenty years, from 1888 to 1908 , Peano devoted all his energies to formulating and realising a project, which throughout his life he was to acknowledge as one of the most important results of his mathematical research ${ }^{1}$. This was the Formulaire de Mathématiques, a huge collection of mathematical propositions expressed in symbols, especially written with his own logic, capable of concentrating in a single volume the knowledge of mathematics of his time. To this end, Peano founded a journal and invited to collaborate on it scholars, assistants, colleagues at the University and at the military Academy, teachers and other mathematicians in Italy and abroad. His total commitment to this enterprise was also accompanied by his voluntary decision to leave his post as Professor of infinitesimal Calculus at the military Academy ${ }^{2}$, keeping only his University position, and by the purchase of

\footnotetext{
${ }^{1}$ Peano (1916e), 8: "Formulario Mathematico t. V, a. 1908 è un trattato più completo dei miei precedenti di Calcolo infinitesimale, incluse le parti introduttorie, Aritmetica, Algebra e Geometria." (The Formulario 5th edition of 1908 is a treatise of infinitesimal Calculus, more complete than my previous ones, including the preliminary parts of Arithmetic, Algebra and Geometry).

${ }^{2}$ From the documents held at the military Academy and from Peano's correspondence with his collaborators it emerges that he himself presented his resignation in order to devote himself full time to other occupations, such as the publication of the Formulario. Cf. Peano's letter to F. Amodeo, 22 February 1901, in F. Palladino, N. Palladino (2006), 252. Cf. also the minutes of 18 February 1901 in Torino Military Academy Archive: "Il Prof. Cav. Peano ha presentato le dimissioni da insegnante presso questa Accademia Militare ed il Ministero della Guerra con suo dispaccio del 14 corrente le ha accettate. Nel dare la partecipazione di questa Superiore disposizione esprimo il dispiacere vivissimo da me provato che venga a mancare all'Accademia l'opera efficace del
} 
a printing press so that he could set up the text himself, in view of the difficulties that the mathematical symbols created for the publishing houses ${ }^{3}$.

This paper will highlight the genesis and the aims of the project, the main sources of inspiration, the stages of realisation and some differences among the five editions, the difficulties and the limits remarked by Peano himself in the course of his work, the controversies and debates on the front of research and teaching, and finally some of the cultural influences and repercussions.

There are four main areas in which the enterprise of the Formulaire was gradually built up: mathematics, logic, history and language, i.e. the 'mathematical vocabulary' and how it could be spread. The first and second dictated the contents and made possible the organisation, while the history and language had the role of creating a context in which for the first time these concepts, definitions, theorems, methods, etc. had been conceived, and of communicating them exactly and rigorously to the widest possible public. Here we shall dwell above all on mathematics and on its history, since logic and language have already been the subject of thorough historical articles to which we make reference ${ }^{4}$.

\subsection{The Genesis and Aims of the Formulario}

From the 1890s, influenced by research on the foundations of mathematics, by the discovery of logic, and by the philosophy of positivism which pervaded the sciences of the time, in his Rivista di Matematica Peano stressed the importance of collecting and cataloguing the theorems, with a view to the development of new research:

It would be extremely useful to publish the collections of all the theorems now known referring to given branches of the mathematical sciences in such a way that the scholar need not consult this collection in order to know how much had been done on a given point, and whether his research was new or not. Such a collection, extremely difficult and lengthy in ordinary language, is notably facilitated by the use of the notations of mathematical logic; and the

Prof. Peano per l'istruzione degli Allievi, ed il prestigio che ad essa procurava la spiccata personalità del Prof. Peano e la reputazione da lui acquisita nel mondo scientifico." Hence the affirmations of H.C. Kennedy on "an undesired interruption" of his teaching at the military school do not correspond to the facts. (H.C. Kennedy (1980), 101).

${ }^{3}$ Peano had bought the printing press from the typography of F. Faà di Bruno, who had been his professor at the University. He installed it in his villa in Cavoretto, and for three months went to a workshop in Turin to learn the art of typographical composition, and he paid three workers to help him with the printing at his own home.

${ }^{4}$ U. Cassina (1955), 244-265, 544-574; N.I. Styazhkin (1969), 276-282; G. Lolli, 'Quasi alphabetum: logica ed enciclopedia in G. Peano', in G. Lolli (1985), 49-83; F.A. Rodriguez-Consuegra (1991), 91-113; W.O. Quine (1986), 33-43; I. Grattan-Guinness (1986), 17-31; (ed.) Philip E.B. Jourdain (1999); E.A. Zaitsev (1994), 367-383; I. Grattan-Guinness (2000), 219-267. As far as concern the language cf. C.S. Roero (1999), 159-182 and E. Luciano, C.S. Roero (2005), LXLXV. 
collection of the theorems on a given subject perhaps becomes less long than its bibliography. ${ }^{5}$

Like many of his contemporaries, he was fascinated by the Encyclopädie der Mathematischen Wissenschaften which was being published in Leipzig, because it provided "an excellent collection of results" , and he read with interest the archives and collections of formulae published by W. Laska and J.G. Hagen and subsequently, in Italy, by E. Pascal ${ }^{7}$.

In addition Peano, who in his youth had cultivated classical studies and a passion for history, loved to read the works of mathematicians of the past and articles and books on the history of mathematics and on logic. Like others before him, at the end of one century or the beginning of the next ${ }^{8}$, he too decided to leave to posterity an encyclopaedic work, written in condensed form by means of symbols, useful not only as a source of inspiration for new studies and research, but as a basis of comparison with other axiomatic arrangements or treatises, as a catalogue of results in mathematics and in history, and finally as a bibliographical list.

On 25 August 1894 he described the features of the project, which he was in the process of writing, to Felix Klein:

And here I pause for a moment, in order to draw your attention to mathematical Logic, and to the Formulario. Mathematical logic with a very limited number of signs ( 7 used, and these can be reduced still further) has succeeded in expressing all the logical relations imaginable between classes and propositions; or rather the analysis of these relations has led to the use of these signs, with which everything can be expressed, even the most complicated relations, which it is difficult and laborious to express with ordinary language. But its advantage is not limited to the simplification of writing; its usefulness lies especially in the analysis of the ideas and reasonings that are carried out in mathematics. Meanwhile, to illustrate its usefulness, the Formulario of mathematics is being printed. [...] Each of the parts dealt with must contain all the propositions, theorems and definitions, to which reference is made. Since, once the Formulario is well advanced, anyone may wish to get up to date on science, on a given point already dealt with in the Formulario, he need only

\footnotetext{
${ }^{5}$ G. Peano (1892k), 76: "Sarebbe cosa della più grande utilità il pubblicare delle raccolte di tutti i teoremi ora noti riferentisi a dati rami delle scienze matematiche, sicché lo studioso non abbia che a confrontare siffatta raccolta onde sapere quanto fu fatto sopra un dato punto, e se una sua ricerca sia nuova ovvero no. Una siffatta raccolta, difficilissima e lunga col linguaggio comune, è notevolmente facilitata servendoci delle notazioni della logica matematica; e la raccolta dei teoremi su un dato soggetto diventa forse meno lunga della sua bibliografia."

${ }^{6}$ Peano (1916e), 1.

${ }^{7}$ Cf. Peano (1892k), 77; W. Laska (1888-1894); J.G. Hagen (1891); E. Pascal, Repertorium der höheren Analysis, Leipzig, Teubner, 2 vol., 1910.

8 This is the case of Luca Pacioli's Summa (1494), of the collections of classics prepared by Christophorus Clavius and by Francesco Maurolico, with comments and developments of contemporaries in the 16th century, of the Cursus seu Mundus Mathematicus (1690) by Claude François Milliet Descales, of Christian Wolff's Elementa Matheseos universae at the beginning of the 18th century, etc.
} 
look it up and will find all the known propositions there. [...] Quotations and historical information make it possible to compare books where the questions are discussed at greater length. This Formulario could not be put into effect in ordinary language. But it becomes possible, and relatively simple with the notations of mathematical logic. These not only condense the writing, but show that many propositions which, in ordinary language, seem to be distinct, are transformed into symbols in the same way, and hence are actually one and the same proposition. I could cite many so-called theories, which, translated into symbols, vanish; they vanish only apparently because the name of an old idea has been changed. Suffice it to say that a fair number of parts of Dedekind's theory of fields, modules, are simply logical propositions and hence are contained in part I of the Formulario. I am now going in for the composition of this Formulario; and every day a new part is translated into symbols. For the translation into symbols of a part of mathematics is no easy matter at present; one must examine all the ideas that appear in it, and reduce them to the smallest possible number. So far it is the parts of Analysis that are most easily transformed; in these, in fact, are found a smaller number of fundamental ideas; but let us hope that before very long Geometry too will be analysed, and translated into symbols. I am working on the publication of the Formulario, and am happy to have the collaboration of a number of colleagues, and of several recent young graduates, who have taken on the various parts with enthusiasm. But my efforts are directed at making known these methods to the scientific world. ${ }^{9}$

Peano asked his German colleague about the possibility of forming other systems of symbols, in order to represent precisely all mathematical ideas, systems that would be easier and better than the one he was developing, and he concluded:

So I will not cease to work on this, until the importance of the question is sufficiently recognised.

He had already presented his project for the Formulario in France, at Caen, at the conference of the Association française pour l'avancement des sciences and on 6 November 1894, writing to Camille Jordan, he reaffirmed the great importance of the logic:

C'est la première fois qu'on a appliqué la logique mathématique à l'analyse d'une question de mathématiques supérieures; et cette application est, selon moi, la chose plus importante de mon travail. Mais les symboles et les opérations de la logique exigent du temps pour être appris; et ma démonstration est peu connue. M. Mie a publié un article explicatif dans les Mathematische Annalen, Bd. 43, p. 553. Mais ensuite ont parus plusieurs travaux sur le même sujet, sans y ajouter rien de nouveau (sauf quelque inexactitude), et sans faire mention de mon travail. Je regrette cela, parce que je crois que la logique

${ }^{9}$ G. Peano to F. Klein, 25 August 1894, in M. Segre (1997), 119-120, repr. E. Luciano, C.S. Roero (2008), 91-92. Cf. also G. Peano to G. Frege, 10 February 1894 and 14 October 1896, in C. Mangione (1983), 146-147, 158-162. 
mathématique apportera des grands avantages dans l'analyse des questions difficiles. $^{10}$

Peano's conception of logic and its goals emerges in numerous points of the Formulario. Logic is an instrument not only of expression, but above all of research, a cognitive tool, which makes it possible to "analyse" mathematics and "make it rigorous" $"$. With this tool one can examine the principles of arithmetic, of geometry and of any other theory, in order to single out the primitive ideas and those which are derived, the definitions, the axioms and the theorems:

L'idéographie, qui résulte de la combinaison des symboles logiques avec les algébriques, a été bientôt appliquée par divers Auteurs. Dans quelques travaux elle sert seulement à énoncer sous forme plus claire des théorèmes. En général elle est l'instrument indispensable pour analyser les principes de l'Arithmétique et de la Géométrie, et pour y démêler les idées primitives, les dérivées, les définitions, les axiomes et les théorèmes. ${ }^{12}$

Though he understood all the importance of theoretical studies of logic, Peano insisted that his aim in the Formulario was the application of logic to mathematics:

Comme vous le remarquez bien, mon but est d'appliquer la logique aux sciences mathématiques. Je comprends toute l'importance des études théoriques sur la logique; mais, vu la vastité de ces études, je préfère de diriger mes forces du côté de l'application. ${ }^{13}$

In his school Pieri chose the image of the microscope to define the capabilities of the 'mathematical' logic tool, in the hands of the researcher, presenting it in Paris at the international philosophy conference in 1900:

La Logique mathématique ressemble à un microscope propre à observer les plus petites différences d'idées, différences que les défauts du langage ordinaire rendent le plus souvent imperceptibles, en l'absence de quelque instrument qui les agrandisse. Quiconque méprise les avantages d'un tel instrument, notamment dans cet ordre d'études (où souvent l'erreur résulte d'équivoques

${ }^{10}$ G. Peano to C. Jordan, 6 November 1894, in M.T. Borgato (1991), 96.

${ }^{11}$ Cf. Lolli (1985), 49-83 and C. Cellucci (1993), 73-138.

12 Cf. G. Peano (1901b), v; cf. also Peano (1913i), 48: "Symbolismo da alas ad mente de homo; sed suo usu exige studio et labore. Illos que, per defectu de exercitio, judica que symbolismo es ligamen, non es obligato ad adopta illo. Nos strue novo instrumento, et non destrue instrumentos existente. [...] Auctores adopta, in parte, symbolos de Formulario mathematico. In aliquo casu, illos varia aut forma aut extensione de symbolos; et introduce numeroso symbolo novo. Ratione de divergentia es scopo differente de symbolismo in Formulario et in libro de Auctores. In Formulario, logica-mathematica es solo instrumento pro exprime et tracta propositiones de mathematica commune; non es fine ad se; logica-mathematica es explicato in 16 pagina; uno hora de studio suffice pro cognosce quod es necessario in applicationes de isto novo scientia ad mathematica. Libro de nostro Auctores tracta logica-mathematica ut scientia in se, et suo applicationes ad theoria de numeros transfinito de vario ordine; quod exige symbolismo multo plus amplo."

13 G. Peano to L. Couturat, 1 June 1899, in E. Luciano, C.S. Roero (2005), 19. 
et de malentendus dans des détails en apparence insignifiants) se prive à mon avis, de propos délibéré, du plus puissant auxiliaire qu'on possède aujourd'hui pour soutenir et diriger notre esprit dans les opérations intellectuelles qui réclament une grande précision. ${ }^{14}$

Peano was also well aware of the difficulties and the limits he was facing, and of the necessity of a collective action and revision, whose amplifier was the Rivista, and he had involved new young graduates and researchers:

Naturally every new work presents hitches. Here and there gaps are still easily perceived; but the Rivista di Matematica always gladly welcomes all the additions and corrections that may be indicated; thus in a short time this Formulario will have reached the desirable perfection. ${ }^{15}$

\subsection{The Influence of Leibniz}

Omnis humana ratiocinatio signis quibusdam sive characteribus perficitur. G.W. Leibniz

In the various editions of the Formulario it is clear that the source of inspiration for Peano was the ambitious idea of the Characteristica universalis, conceived by G.W. Leibniz $^{16}$, which gave him the basis for an Enciclopedia generalis:

Leibniz a énoncé, il y a deux siècles, le projet de créer une écriture universelle [...] Il dit : "Ea si recte constituta fuerit et ingeniose, scriptura haec universalis aeque erit facilis quam communis, et quae possit sine omni lexico legi, simulque imbibetur omnium rerum fundamentalis cognitio.” À la solution de ce problème a contribué d'abord le développement de l'écriture algébrique, qui s'est beaucoup perfectionnée après Leibniz. Au moyen des signes ,,$+-=,>$, etc., des parenthèses, et des lettres de l'alphabet, elle permet d'écrire en symboles quelques propositions. Mais ce qui a le plus contribué à la solution du problème, c'est la nouvelle et importante science qu'on appelle Logique mathématique, et qui étudie les propriétés formelles des opérations et des relations de logique. ${ }^{17}$

\footnotetext{
${ }^{14}$ M. Pieri (1901a), 382.
}

15 G. Peano to Felix Klein, 25 August 1894, in M. Segre (1997), 120: "Naturalmente ogni lavoro nuovo presenta degli inconvenienti. Qua e là si scorgono ancora facilmente delle lacune; ma la Rivista di Matematica accoglie sempre con piacere tutte le aggiunte e correzioni che verranno indicate; sicchè fra non molto questo Formulario avrà raggiunta la perfezione desiderabile."

${ }^{16}$ Cf. G.W. Leibniz, Scientia generalis, Characteristica, Calculus universalis, in G.W. Leibniz (1999); E. Pasini (1995), 385-412; M. Mugnai (1996), 61-88; M. Mugnai, E. Pasini (2000); E. Luciano (2006), 525-531.

${ }^{17}$ Peano (1894g), 3. 
The insistence with which Peano acknowledged his cultural debt to Leibniz was not simply a manner of speaking in order to promote his contemporaries' approval of the project, by pointing to the German philosopher and mathematician as his distinguished predecessor. In his personal library were found the editions of Leibniz's works and manuscripts, as well as many notes with passages taken from various of Leibniz's essays, all testifying to a constant, profound interest throughout his life ${ }^{18}$. Moreover it was Peano who suggested to his student Vacca that he should go to Hanover in 1899 to examine Leibniz's unpublished works, and who acted as gobetween with Couturat for the continuation of the French philosopher's historical research, the fruits of which appeared in the two massive volumes La logique de Leibniz and the Opuscules et fragments inédits de Leibniz ${ }^{19}$.

In 1896 Peano several times returned to the fulfilment of Leibniz's dream of producing "une spécieuse générale ou une manière de langue ou d'écriture universelle, où toutes les vérités de raison seraient réduites à une façon de calcul" 20 . Like Leibniz, he held that it was one of the main problems to be faced and that it had as much value in science as the discovery of the telescope and the microscope $^{21}$. The echoes of Leibniz's remarks are almost identical to the German's original words, and are scattered throughout the writings of Peano and his collaborators. They insisted that mathematical logic is not simply a tachigrafy, but a "sort of calculus" which not only made the exposition of mathematics simpler and clearer, but made it possible to distinguish primitive ideas, derived ideas, definitions, axioms and theorems:

Car toutes les recherches qui dépendent du raisonnement se feroient par la transposition de ces caractères, et par une espèce de calcul; ce qui rendroit l'invention des belles choses tout a fait aisée. Car il ne faudroit pas se rompe la teste autant qu'on est obligé de faire aujourd'huy, et neantmoins on seroit asseuré de pouvoir faire tout ce qui seroit faisable, ex datis. ${ }^{22}$

\footnotetext{
${ }^{18}$ In Peano's manuscript notes it is clear that the topics dealt with from Leibniz's works concerned logic, the international language, minimum simplified Latin, binary arithmetic, analysis, the theory of determinants, the encyclopaedia, the history of mathematics, etc.

${ }^{19}$ G. Vacca (1899), 113-116; (1903), 64-74; L. Couturat (1901); (1903); G. Vailati (1901a), 148159; (1901b), 103-110.

${ }^{20}$ G. Peano (1896i), 169.

${ }^{21}$ G. Peano (1896b), 1: "Il [Leibniz] énonce ce projet dans son premier travail, ou, comme il l'appelle, dans son "essai d'écolier" intitulé "De arte combinatoria a. 1666". Il fixe le temps nécessaire à la former : "aliquot selectos homines rem intra quinquennium absolvere posse puto". Il trouve cette découverte plus importante que l'invention des télescopes et des microscopes; elle est l'étoile polaire du raisonnement ... Dans ses dernières lettres il regrette "que si j'avois été moins distrait, ou si j'étois plus jeune, ou assisté par des jeunes gents bien disposés, j'espérerois donner une manière de cette spécieuse (p. 701)". Il dit aussi (p. 703) "J'ai parlé de ma spécieuse générale à Mr. Le Marquis de l'Hospital, et à d'autres ; mais ils n'y ont point donné plus d'attention que si je leur avois conté un songe."

${ }^{22}$ Cf. G.W. Leibniz, 'Linguae Philosophicae Specimen in Geometriam edendum', 1680, in G.W. Leibniz (1999), vol. 4, 155.
} 
But the main use of the symbols of logic is that they facilitate reasoning [...] So symbolism is clearer; make it possible to develop series of reasonings when the imagination would be quite unable to maintain itself without symbolic aid. ${ }^{23}$

This ideography, which derives from the studies of mathematical logic, is not just a conventional abbreviated way of writing, or tachigraphy. Thus our symbols do not represent words, but ideas. So one must write the same symbol, where one finds the same idea, whatever the expression used in ordinary language to represent it : and different symbols must be used, where one finds the same word, which because of its position, represents different ideas. $^{24}$

Proudly, Peano said he had been successful:

Nous avons donc la solution du problème proposé par Leibniz. Je dis "la solution" et non "une solution", car elle est unique. La Logique mathématique, la nouvelle science composée de ces recherches, a pour objet les propriétés des opérations et des relations de logique. Son objet est donc un ensemble de vérités, et non de conventions [...] Ces résultats sont merveilleux, et bien dignes des éloges de Leibniz à la science qu'il avait deviné. ${ }^{25}$

Peano also shared the concept of the role that the history of mathematics had in research, both as a source of inspiration to increase the ars inveniendi, as Leibniz maintained, and to attribute the "paternity" of the results. History is useful for the instruction of the young in that it makes the study of mathematics more attractive. This was why scientific literature should be side by side with humanistic literature. The historical introduction is, in fact, of great utility to show that mathematics is not a static nor a dogmatic science, that it is not a set of rules or formulae, but the fruit of a development of human thinking. Hence in the Formulario great attention was given to identifying the authors of concepts, theorems, methods, symbols, to the research dome by earlier scholars, to the history of signs, etc. Peano was in the habit of introducing into his university lectures much information about the history of mathematics. His assistant Vacca, who inherited the same passion for history, recalled:

${ }^{23}$ G. Peano (1915j), 170, 172: "Ma l'utilità principale dei simboli di logica si è che essi facilitano il ragionamento [...] Perciò il simbolismo è più chiaro; permette di costruire serie di ragionamenti quando l'immaginazione sarebbe interamente inabile a sostenere se stessa senza aiuto simbolico."

${ }^{24}$ G. Peano (1896j), 565-583: "Questa ideografia, che deriva dagli studii di logica matematica, non è solo una scrittura convenzionale abbreviata, o tachigrafia. Poiché i nostri simboli non rappresentano delle parole, ma delle idee. Si dovrà pertanto scrivere lo stesso simbolo, ove trovasi una stessa idea, qualunque sia l'espressione usata dal linguaggio ordinario per rappresentarla: e si dovranno usare simboli distinti, ove trovasi una stessa parola, che, a causa della sua posizione, rappresenta idee distinte."

${ }^{25}$ G. Peano (1896b), 2. 
He knew by heart, and willingly repeated, long pages of Newton's Principia and of the two famous letters from Newton to Leibniz. He admired (with Abel) Cauchy's clear volume, the Cours d'Analyse (1821) [...] His lectures, different every year, represented a constant effort to arrive at clearer expositions. I remember the first part of the 1903 course, begun following Bonaventura Cavalieri's geometric methods of the indivisibles. I remember the lectures on the theory of irrational numbers, illustrated with the Fifth Book of Euclid, the lectures on the rectification of curves, starting from the expositions of Archimedes. Finally, I remember the reading of the pages of Galileo and of Torricelli on the fall of heavy bodies, and the lectures on the calculus of variations, in which he interpreted in a new form the classic memories of Euler and of Lagrange. ${ }^{26}$

The editions of 1897-99, 1901 and 1903 are rich in historical Notes which accompany the various sections. Peano pointed out their importance in his Rivista and as editor, together with Vacca and Vailati, stressed the need for absolute precision if they were to be really useful:

The historical indications, both as to the propositions, and to the notations, always useful, are especially so in the Formulaire, because they rest the reader a little, and show better the importance of the propositions, and often the advantage of the ideography. But they too require much labour in order to have some value. The indications found in the books of the past generations, and also in some modern books [...] have no precision at all [...] In consequence one has to go back to the origin of the quoted passages; and the quotations in Formulaire are accompanied by precise indications, so that anyone can easily compare the quoted passage; and often the cited passage is repeated. This as far as it was possible; because in the Formulaire too, some quotations await greater specification. Note too that the historical indications contained in the Formulaire do not pretend at all to go back to the first origin of the [proposition] in question; but simply to indicate an Author where it is found. A further study will be able to substitute for them other citations relative to a more ancient period. After all, here use has been made of the historical research of M. Marie, M. Cantor, of those contained in the Intermédiaire des Mathématiciens, and in various other works mentioned. ${ }^{27}$

From 1901 the philological-linguistic aspect of mathematical terms was also taken into account, with the gradual insertion of a mathematical Dictionary ${ }^{28}$.

The Formulaire was intended to be to all effects an encyclopaedia in which the reader would be able to find mathematics, history and philology. The readership to

\footnotetext{
${ }^{26}$ G. Vacca (1933), 97-99.

${ }^{27}$ G. Peano (1898e), 83, 85-86.

${ }^{28}$ The Dizionario di Matematica begun by Peano and Vailati included the section on Logic and was presented in 1901 in Leghorn to the teachers of the Italian Associazione Mathesis. Cf. Peano (1901j), 160-172.
} 
whom it was mainly addressed was composed of university colleagues, students and teachers. In this context of the encyclopaedia too the inspiration of Leibniz can be $\operatorname{seen}^{29}$ :

A Dictionary of Mathematics, that is, a collection of terms that are met with in the current mathematical works, together with the remarks that serve to specify the meaning or meanings of every term, such as the etymology, the history, the definition, when possible, will be a work which is useful as much from the scientific as from the didactic point of view. The multiplicity of terms used to represent a single idea, and the multiplicity of meanings in which a single term has been used are an all too widespread and well-known inconvenience. The dictionary will be capable of guiding every author individually in the choice of the most suitable terms for his work. ${ }^{30}$

With regard to the international language too, Peano acknowledged his cultural debt to Leibniz, whose echo can be heard in many passages:

Leibniz went into this subject in depth and at length, but published nothing. His study has remained buried in the Hanover library to this day. Some of his manuscripts were discovered and published first by Vacca in the RdM, then by Couturat in Opuscules et fragments inédits de Leibniz, Paris a. 1903, p. XVI-682, which contains Leibniz's study, invaluable for the assembling of the Philosophical Dictionary. If analysis and synthesis should come together in the future, like two teams of miners working in a tunnel from its opposite ends, then Leibniz's "Rational Language" and "Universal Characteristic" will do likewise." See also: H. Diels, Über Leibniz und das Problem der Universalsprache, Berlin, Sitzung. d. Akademie, a. 1899 p. $579 .{ }^{31}$

${ }^{29}$ G.W. Leibniz, 'Initia et Specimina Scientiae Generalis', 1679, n. 86, in G.W. Leibniz (1999), 360: "Consilium de Encyclopaedia condenda, velut Inventario cognitionis humanae condendo in quod referantur utiliora, certiora, universaliora et magis sufficientia pro reliquis omnibus determinandis; quacunque sive in melioribus autoribus extant sive inter homines in primis certa vivendi genera sectantibus adhuc latent, additis semper rationibus eorum quae fiunt originibusque inventionibus. Quod opus non nimis erit prolixum ... Hujus operas usus erit ut occurratur confusioni librorum eadem repetentium, paucaque interdum utilia sub magna farragine obruentium, si sit Basis aliqua ad quam omnia imposterum nova per modum supplementorum referri possint."

${ }^{30}$ G. Peano (1901j), 1: "Un Dizionario di Matematica, cioè una raccolta dei termini che si incontrano nelle opere matematiche attuali, insieme alle osservazioni che servono a precisare il significato o i significati d'ogni termine, quali l'etimologia, la storia, la definizione, quando è possibile, riuscirà un lavoro utile tanto sotto l'aspetto scientifico quanto sotto quello didattico. La moltiplicità dei termini usati per rappresentare una stessa idea, e la moltiplicità dei significati in cui è usato uno stesso termine costituiscono un inconveniente troppo diffuso e ben noto. Il dizionario potrà guidare individualmente ogni autore nella scelta dei termini più opportuni pel suo lavoro." G. Peano (1903f), viii: "Le Formulaire maintenant, par l'abondance des propositions, des indications historiques et bibliographiques joue le rôle d'une Encyclopédie. Toutes les idées du Formulaire sont introduites par des définitions régulières. Dans plusieurs théories les propositions sont accompagnées de la démonstration (et aussi de plusieurs démonstrations)."

${ }^{31}$ G. Peano (1903d), 80, 82. 


\subsection{The Stages of the Production of the Formulario}

From correspondence with his students and collaborators and from materials recently rediscovered on Peano's personal library and in the archives of Vacca, Vailati and Cassina, it is possible to reconstruct the stages of production and the changes in editorial choices ${ }^{32}$. Chronological scanning of the contents and the indication of the contributions of the various authors and of the main novelties can be seen in Tables 1-5, which summarises the information obtained from the marginalia and from the galley proofs ${ }^{33}$. From the very first, the Formulaire was conceived as a collective work. Peano stressed this aspect in the first edition and in 27 points laid out the rules that future collaborators would have to follow in writing the chapters. ${ }^{34}$ Payment consisted in the annual subscription to his Rivista di Matematica.

32 The rediscovery of the catalogue of Peano's personal library has made it possible to trace the volumes belonged to him and to identify those with autograph marginal notes. Some of these volumes were sold between 1935 and 1938 to the Library of the Department of Mathematics of the University of Milan (BDM Milano) to finance the journal Schola et Vita; others are held in the Fondo Cassina of the Library of the Department of Mathematics of the University of Parma, and yet others in the Lascito Peano at the Cuneo Civic Library. Cf. E. Luciano, C.S. Roero (2008), 8688 and website www.peano2008.unito.it. Peano's correspondence, donated in 1954 to the Cuneo Civic Library by Cassina and Gliozzi, is available in digital format on the cd-rom of C.S. Roero, N. Nervo, T. Armano (2002). In the Library of the G. Peano Department of Mathematics at the University of Torino the acquisition has recently been made of documents, books, correspondence and manuscripts which were in possession of G. Vacca, of M. Gliozzi, and N. Mastropaolo, and this is currently being catalogued. Among the papers there are the proofs of the Formulario sent by Peano to Vacca, with his corrections and marginal notes. Among the books there are some editions of the Formulario with Vacca's marginal notes and comments.

${ }^{33}$ The volumes of the Formulario with Peano's autograph notes are reproduced on the dvd of C.S. Roero (2008). The texts in question are Peano (1894g)* Notations de logique mathématique (Introduction au Formulaire), Torino, Guadagnini (BDM Milano: Op. I 46); (1895r)* Formulaire de Mathématiques, tome 1 publié par la Rivista di matematica, Torino, Bocca (BDM Milano: Op. I 46); (1895r)** Formulaire de Mathématiques, tome 1 publié par la Rivista di matematica, Torino, Bocca (BDM Milano: Op. A 138); (1897b)* Formulaire de Mathématiques, t. II, n. 1, Logique mathématique, Torino, Bocca (BDM Milano: Op. A 140); (1897e)* Formulaire de Mathématiques, t. II §1, "Logique mathématique", Turin, Bocca-Clausen (BDM Milano: Op. I 46); (1898h)* Formulaire de mathématiques, t. II, §2 Aritmetica, Torino, Bocca (BDM Milano: Op. I 46); (1899b)* Formulaire de Mathématiques, t. II, n. 3, Torino, Bocca (BDM Milano: Op. I 46); (1901a)* Formulaire de Mathématiques, t. III. Turin, Bocca-Clausen (BDM Milano: Op. I 46); (1903f)* Formulaire mathèmatique, tome IV de l'èdition complète, Torino, Bocca (BDM Parma: Per 0831709 999653); (1906g)* Formulario mathematico ed. V. Indice et Vocabulario, Torino, Bocca (BDM Milano: Op. A 139); (1908a)* Formulario Mathematico, t. V, Torino, Bocca (BDM Milano: Op. A 141). The examination of all Peano's autograph notes and of those of his followers in copies of the various editions of the Formulario, together with the critical reading of the correspondence of those who were actively engaged in the undertaking, and with the analysis of the manuscript notes given by Peano to Vacca, when the latter was his assistant in Turin, with the proofs annotated by Peano and by Vacca, will cast new light on the whole story and may perhaps clarify some of the problems rightly pointed out in Grattan-Guinness (2000), 262-267.

${ }^{34}$ G. Peano (1895aa), 'Preface', iii-vii. 
The fact that the Formulaire was work in progress was repeated on many occasions:

Quelques théories sont déjà suffisamment analysée, mais dans d'autres cas il n'y a que l'énoncé de quelque propositions, pour indiquer la place où un collaborateur de bonne volonté pourra insérer une théorie complète. Ces lacunes sont inévitables dans notre publication, car le Formulaire, toujours en construction, procède par perfectionnements successifs ; d'un coté l'on ordonne et complète des théories, déjà publiées, de l'autre on introduit les esquisse de théorie nouvelles, qu'on perfectionnera dans la suite. ${ }^{35}$

A constant exchange with readers was activated both in the Rivista di Matematica, and in the Prefaces. In the preface to the 2nd edition, for example, composed on 11 August 1897, Peano inserted a note to the effect that the most important propositions were indicated with an asterisk ${ }^{36}$. Among the most important novelties of this edition is the presence of many original passages from historical sources (not only books, but also manuscripts and correspondence and the introduction of the concepts of ordered couple, of the symbols $F$ for the defined function and $\exists$ for the existential quantifier, the change in the axioms of arithmetic of 0 in place of 1 , and the statements of his theorems on the systems of several differential equations. In the 3rd edition, published on 1 January 1901, the historical parts, edited by Vacca and by Vailati, are further amplified with passages in Greek from Aristotle, Euclid, Apollonius and Diophantus ${ }^{37}$. Peano here introduces the analytical functions, the transformations of vectors (1895q) and completes the parts on the derivatives, on the integrals and on the complex numbers. In the section on the primitive propositions of arithmetic is inserted the variation proposed by Padoa in Rome in $1900^{38}$, which makes it possible to reduce their number.

Peano was well aware of the limitations and of the difficulties to be overcome, but he was also optimistic and trusted in the contribution that many collaborators would offer. He was reading, studying, making comparisons with other layouts, convinced that he was offering one possible structure on which mathematics could be based, not the only one possible. On this point he wrote to his assistants in 1902 and in 1905:

These difficulties which are encountered in Mathematical Logic are not worrying. I remember that in ' $88 \mathrm{I}$ introduced the sign ' $x \ni$ ' in another form, as well as following Schröder, but I met with difficulty in the sign of deduction, still only one both for the general and for the individual Props. This difficulty was resolved in 1889 with the distinction of the two signs ' $\in$ ' and ' $\supset$ '. Other difficulties, which made certain transformations impossible with fixed rules,

${ }^{35}$ G. Peano (1898f), ii. Cf. also Peano (1901b), vii: "Le Formulaire est toujours en construction ... on trouvera ici la place d'une proposition, déjà écrite en symboles, à peu près comme on trouve la place d'un mot dans un dictionnaire."

${ }^{36}$ Peano (1897b), 2.

${ }^{37}$ Cf. G. Vailati to G. Vacca, 16 December 1899, in G. Lanaro (1971) and Vacca to Vailati, 6 April 1905, in E. Luciano, C.S. Roero (2008), 101.

${ }^{38}$ A. Padoa (1901a). 
were solved with the introduction of the signs ' $l$ ' and ' $\urcorner$ ', which I think was done in 1890. Another difficulty presented itself and was solved with the two signs ' $f$ ' and ' $F$ '. It may be that there are others. But I have great faith that these too will find a way to become quite clear, and in consequence to be solved. In this difficulty Burali found himself, in his article in the RdM. It is intimately linked to the theory of the relations or classes of couples, studied by Russell, to which he and Whitehead attribute great importance, I do not know whether rightly or wrongly, because I have not yet formed a clear idea of this study. ${ }^{39}$

I am not worried about the application that my contemporaries may make of it, and much less those in the future. However, once the first astonishment has passed, it is possible that many may think it useful to create the same tool, or a similar tool, to express similar ideas [... ] In the system of symbols adopted in the Formulario, the possibility emerges to recognise the apparent letter from its position with regard to the three signs ' $\supset \ni /$ '. But in another ideography - and several are possible - and I would be very glad to see others arise - which would not at all mean damaging competition - it may be that the variable letter is accompanied by a single sign. ${ }^{40}$

In the review of Whitehead and Russell's Principia, which he often praised in his writings, Peano affirmed:

Symbolism gives wings to the human mind, but its use requires study and effort. Those who for lack of exercise regard symbolism as a liability, are not obliged to adopt it. We are building a new tool and we are not destroying the existing tools. ${ }^{41}$

He was always fond of the product he had conceived, as were his pupils, who did not attempt to follow other authors, such as Russell and Hilbert, but in the end were still walking the path trodden by the Peano in the 1940s and '50s.

In the 4th edition (1903) the novelties regarded continuous fractions, calculus of differences, probability, elementary geometry, the applications of differential geometry to twenty or so curves, the singularities of real curves, the definition of the area of a curved surface (Peano-Schwarz) and the definition of the length of a curve. The part regarding the vocabulary of mathematics and the biographical information was greatly expanded, edited by Vacca. In 1906 a limited print run of 100 copies of the 5 th edition, in the international language encouraged by Peano, latino sine flexione, which in June 1908 appeared on its definitive form. Here we find the bibliography of texts on mathematical logic published between 1900 and $1908^{42}$.

${ }^{39}$ G. Peano to G. Vacca, 28 December 1902, in Fondo Peano-Vacca, Dep. Mathematics Peano University of Torino.

${ }^{40}$ G. Peano to G. Vailati and G. Vacca, 29 November 1905, in Fondo Peano-Vacca, Dep. Mathematics Peano University of Torino.

${ }^{41}$ G. Peano (1913i), 48.

${ }^{42}$ Among the authors quoted, outside Peano's circle, are L. Couturat, E. Huntington, P.H. Jourdain, E.H. Moore, B. Russell, O. Veblen, A.N. Whitehead, A.T. Shearman. 
While Peano originally aspired to provide an encyclopaedia of higher mathematics, in symbolic form, what he actually succeeded in producing was a compendium of elementary mathematics, i.e. the notions that were imparted in Italy in the first two years of university study of mathematics. Apropos the suppression of parts of advanced mathematics, which had been inserted in previous editions, such as the theory of algebraic numbers edited by Fano, the motivation Peano put forward was that ideas that are not precise and theories that are not consolidated cannot be represented, and that the main objective was rigour:

But rigour does not proceed by degrees to the infinite. The books of one generation do not destroy, but rather complete the books of the preceding generation. The solution of some obscure point is not given by books of great bulk, but by a new combination of known ideas. [...] The Formulario, fairly complete as regards the mathematics of past centuries, is very incomplete for the modern, living authors. In fact the reduction of a theory to symbols demands the analysis of all the ideas, the enunciation of all the hypotheses, a lengthy and often difficult business. Many modern theories are not sufficiently rigorous. The Formulario does not contain all the propositions already reduced to symbols. There are many other applications of Mathematical Logic to different questions made by many authors who adopt the symbols and the methods of Mathematical Logic. ${ }^{43}$

Moreover Peano was constantly using his Formulario in his teaching, as is testified both by the syllabi of his courses (which are simply the index of the Formulario), and by the handouts prepared by his students Meriano and de Finis. He also held an open free course on mathematical Logic in the academic year 1906-07, during which he developed the following topics:

Ideas of Logic that arise in mathematics. Equality, deduction. Syllogism, according to Aristotle. Commutative and associative properties of multiplication and logical addition according to Leibniz. Distributive properties according to Lambert. Algebra of Logic, according to Boole and Schröder. Characteristics of mathematical definitions. Primitive ideas and derived ideas. Characteristics of mathematical proofs. Primitive propositions and Theorems. Analysis of the principles of Arithmetic, according to Dedekind, and Russell. Analysis of the principles of Geometry, according to Pieri and Hilbert. Theory of groups of points, cardinal numbers and transfinite ordinal numbers, according to Can-

\footnotetext{
${ }^{43}$ Peano (1908a), xii-xiii: "Sed rigore non procede per gradu, usque ad infinito. Libros de uno generatione non destrue, sed completa libros de generatione praecedente. Solutione de aliquo puncto obscuro non es dato per magno libro, sed per aliquo novo combinatione de ideas noto [...] Formulario, satis completo pro mathematica de seculos praeterito, es multo incompleto pro auctores moderno et vivente. Nam reductione in symbolos de aliquo theoria exige analysi de omni idea, enunciatione de omni hypotesi, quod es longo et saepe difficile. Plure theoria moderno non es satis rigoroso. Formulario non contine omni propositione jam reducto in symbolos; existe numeroso alio applicatione de Logica-Mathematica ad differente quaestiones, per plure Auctore, que adopta symbolos, vel methodos de Logica-Mathematica."
} 
tor. Antinomies which are found, according to Russell, and others. Attempts by Borel, Hadamard, Poincaré, Lebesgue, Baire, Jourdain to solve them. ${ }^{44}$

Also in the courses on infinitesimal Calculus, after the usual explanation of the theorems, Peano went on to the translation of each passage into symbols. There were conflicting reactions from the student audience. At the end of the handouts, which he had prepared, Igino De Finis concluded:

With this we have finished expounding what the syllabus demands, or more correctly has our beloved professor said we have learned to read the Formulaire Mathématique. I think it is my duty to beg pardon of all my colleagues if these few pages have not answered their aim. You all know in what conditions of time I have had to re-order my notes, translate them and then with my own hand write them on lithographic paper. It would be folly and vain pretension on your part if you thought that you would find here that truly original mark of the Lectures that our famous Professor gave us. Only someone who has had the honour of following them all and with the concentration necessary to understand properly such a delicate subject can appreciate how great is the subtlety and the sublime art that transpires from the wise words of Prof. G. Peano; and be rightly proud to have had such a teacher. ${ }^{45}$

On the other hand C. Botto, who attended as a student of Engineering, expressed great perplexity:

The textbook which Peano followed had instead become the Formulaire of which, with supreme love and great patience, he taught the first pages, devoted

${ }^{44}$ G. Peano, Programma di Logica Matematica, corso libero per l'anno 1906-07 presso la R. Università di Torino, Archive University of Torino, Affari ordinati per classe, XIV B 227, Programmi di corsi liberi, Torino 20 March 1906, in E. Luciano, C.S. Roero (2008), 133-134: "Idee di Logica che si presentano in matematica. Eguaglianza, deduzione. Sillogismo, secondo Aristotele. Proprietà commutativa e associativa della moltiplicazione e dell'addizione logica secondo Leibniz. Proprietà distributiva secondo Lambert. Algebra della Logica, secondo Boole e Schröder. Caratteri delle definizioni matematiche. Idee primitive e idee derivate. Caratteri delle dimostrazioni matematiche. Proposizioni primitive e Teoremi. Analisi dei principii di Aritmetica, secondo Dedekind, e Russell. Analisi dei principii di Geometria, secondo Pieri e Hilbert. Teoria dei gruppi di punti, numeri cardinali e numeri ordinali transfiniti, secondo Cantor. Antinomie che vi si riscontrano, secondo Russell, ed altri. Tentativi di Borel, Hadamard, Poincaré, Lebesgue, Baire, Jourdain per risolverle." For the use of the Formulario in his teaching, cf. E. Luciano, 'Un sessantennio di ricerca e di insegnamento dell'Analisi infinitesimale a Torino: da Genocchi a Peano', Quaderni di Storia dell'Università di Torino, 9, 2008, 65-72 and 76-84.

45 G. Peano (1904d), 219-220: "Abbiamo con questo finito di esporre quanto esige il programma, o più propriamente come ha detto il nostro amato professore abbiamo imparato a saper leggere il Formulaire Mathématique. Credo mio dovere il chiedere scusa a tutti i miei colleghi se queste poche pagine non hanno risposto allo scopo. Voi tutti sapete in quali condizioni di tempo io ho dovuto riordinare i miei appunti, tradurli e quindi di mio pugno scriverli su carta litografica. Sarebbe follia e vana pretesa la vostra se credeste trovare qui dentro quell'impronta veramente originale che hanno le Lezioni che il nostro illustre professore ci ha fatte. Solo chi ha avuto l'onore di seguirle tutte e con quel raccoglimento necessario per ben comprendere una materia così delicata può capire quanto grande sia la finezza e l'arte sublime che traspira dalla sapiente parola del Prof. G. Peano; ed essere con diritto orgoglioso di avere avuto un tale maestro." 
to the symbols of logic and then a few lines of some other pages, devoted to very detailed definitions of concepts, to the various operations and to developments of various parts of mathematics. Only in the last few months of the academic year did Peano reach the point of covering briefly, still with his symbols, Calculus with the system of vectors, and expounding some applications to curves, with deductions of length, area, etc. [...] But we students knew that this teaching was too lofty for us, we understood that these very subtle analyses of concepts, these very minute criticisms of the definitions used by other authors, were not suitable for beginners, and especially were of no use to engineering students. We were sorry to have to devote time and effort to "symbols" which in subsequent years we would never again have used. ${ }^{46}$

Firmly convinced of the importance of mathematical logic as a research tool in mathematics, Peano proposed its use to the students in their degree dissertations of Higher Analysis, and to his assistants to go more deeply into concepts and theorems. He wrote to Vacca in 1906:

These properties were born once more in the mind of Boole, from whence, by way of Jevons, Schröder, and others, they arrived at the Formulario, where their importance emerges as research method, and not only their toy laboratory. ${ }^{47}$

I consider it my duty, and that of all those with the responsibility of teachers, to perfect it, with relevant studies and publications That is why I am publishing the Formulario. [...] The questions that are important, useful for our young people immediately, or useful later on, are in heaps in the Formulario; and only a little attention is needed to discover some [...]. So, to be clear and to conclude something, take the proofs of the Formulario favourably; read them with care, wherever they are new to you. You will find many threads that will lead you to use its broad though chaotic knowledge. Others I myself will point out, and thus you can continue to work, and conclude, as you did with the preceding volumes, excel, and in essence do your duty. From this point you can take flight and do those tasks and publications, in which my help would be nil. ${ }^{48}$

${ }^{46}$ C. Botto (1934), 19-20: "il libro di testo che il Peano seguiva era diventato invece il Formulaire del quale Egli insegnava, con sommo amore e grande pazienza, le prime pagine destinate ai simboli della logica e poi alcune linee di alcune altre pagine, dedicate alle accuratissime definizioni dei concetti, alle diverse operazioni e ad alcuni svolgimenti di varie parti della Matematica. Solo negli ultimi mesi dell'anno scolastico il Peano arrivava a svolgere brevemente, sempre con i suoi simboli, il Calcolo col sistema dei vettori, e ad esporre qualche applicazione alle curve, con deduzioni di lunghezze, di aree, ecc. [...] Ma noi studenti sapevamo che quell'insegnamento era troppo alto per noi, capivamo che quelle analisi così sottili dei concetti, quelle critiche così minute delle definizioni usate da altri autori, non erano adatte a dei principianti, e specialmente non servivano a degli allievi ingegneri. Ci spiaceva dover dedicare tempo e fatiche attorno a dei "simboli" che negli anni seguenti non avremmo mai più adoperato."

${ }^{47}$ G. Peano to G. Vacca, 15 November 1906: "Quelle proprietà nacquero un'altra volta nella mente di Boole, donde passando per Jevons, Schröder, ed altri, arrivarono al Formulario, ove ne risulta l'importanza come metodo di ricerca, e non solo il loro ufficio di giocattoli."

48 G. Peano to G. Vacca, 19 February 1905: "Io reputo dovere mio, e di quanti sono incaricati di insegnamento, di perfezionarlo, con studii e pubblicazioni relative. Perciò io pubblico il For- 
In the two academic years 1908-10, in the course on Higher Analysis, Peano made his students study the Formulario more deeply, with other texts with contributions of new, original research expounded with logico-mathematical symbolism. The degree dissertations by Gramegna, Mago and Peyroleri, written under his supervision, were published in the form of articles which show that the Formulario was the main research tool. For instance Mago, in his Teoria degli ordini wrote:

The propositions can be found in my work written not only in ordinary language, but also in symbols. The ideographical signs can be used both to analyse more certainly and to expound briefly, precisely and completely the propositions of logic and of mathematics (and in this sense they are used especially in the Rivista Matematica and in the Formulario published by Peano), and as tools suitable to suggest new classes of entities and constant, I might almost say mechanical, methods with which to develop the theory. Perhaps when their usefulness is quite clear in creating and expounding new mathematical theories which are either of great elegance in themselves or more suited to the description of natural phenomena, around which our knowledge is growing daily more complex, the ideographical signs will gradually come to be universally accepted. ${ }^{49}$

This anomalous kind of teaching and of introducing research in analysis prompted protests from his colleagues, who at the Faculty meeting on 17 March 1910 decided not to renew Peano's appointment to the course on advanced Analysis, forcing him to confine himself to the first two years of university study. Peano confided bitterly to Vacca:

I am giving up advanced teaching, against my will and with great regret. I have done all my lessons, succeeding in interesting the students, who in effect took an interest in it. I succeeded in agreeing with my colleagues, on whom I depend. But they want me to give up symbols, not to talk about the Formulario any longer and still more. I rejected any confirmation on those terms. I held that course out of pleasure and not self-interest. So it's all over. It will be difficult to bring out another volume of the Rivista. I have worked a good deal,

mulario. [...] Le questioni importanti, utili per i nostri giovani immediatamente, o utili più tardi, sono nel Formulario a mucchi; e basta un po' di attenzione per scoprirne alcune. [... ] Dunque, per intenderci, e per conchiudere qualche cosa, prenda alle buone le bozze del Formulario; le legga con attenzione, ovunque sonvi novità. Troverà molti fili che la condurranno ad utilizzare le sue cognizioni ampie, ma caotiche. Altri ne indicherò io stesso, e così potrà continuare a lavorare, e conchiudere, come fece per tomi precedenti, farsi onore, e essenzialmente fare il proprio dovere. Di qui potrà spiccare il volo a fare quei lavori e pubblicazioni, in cui il mio aiuto sarebbe nullo."

49 V. Mago (1912/13), 1-25, in particular note 8: "Le proposizioni si trovano scritte nel mio lavoro oltre che in linguaggio ordinario, anche in simboli. I segni ideografici si possono usare sia per analizzare con maggior sicurezza ed esporre in forma breve, precisa e completa le proposizioni di logica e di matematica (e in questo senso sono specialmente usati nella Rivista Matematica e nel Formulario editi dal Peano), sia come strumenti atti a suggerire nuove classi d'enti e metodi costanti, meccanici, direi quasi, onde svolgerne la teoria. Forse quando sarà del tutto palese la loro utilità nel creare ed esporre nuove teorie matematiche o di grande eleganza in sé o meglio atte alla descrizione dei fenomeni di natura, intorno alla quale la nostra conoscenza si fa di giorno in giorno più complessa, i segni ideografici finiranno a poco a poco per essere universalmente accettati." 
and I have a right to rest, all the more since my colleagues find my theories dangerous. Whoever cares to, can defend the Formulario. Anyway it is already a rather well-known book, and will no longer die. It may be that I will dedicate these last years to interlingua or to gardening. [...] I am a member of the Genoa philosophical society; I enrolled with great ideas, but I have no longer any desire to work. ${ }^{50}$

In the spring of 1910 his mathematical research interests changed and although he continued to follow and read works on mathematical logic he no longer took the field with new, important research and results.

In his review of Whitehead and Russell's Principia he stressed the differences from his enterprise with the Formulario:

The Authors adopt, in part, the symbols from the Formulario mathematico. In some cases they vary either the form or the extent of the symbols and introduce many new symbols. The reason for this divergence is the different aim of the symbolism in the Formulario and in the books by these Authors. In the Formulario mathematical-logic is simply a tool to express and deal with propositions of ordinary mathematics; it is not an end in itself. Mathematicallogic is explained in 16 pages and one hour of study is sufficient to know what is necessary in the applications of this new science to mathematics. In contrast our Authors' book deals with mathematical-logic as science in itself, and its applications to the theory of transfinite numbers of various orders, and this demands a much broader symbolism. ${ }^{51}$

Polemical tones towards the authoritarian, excessively drastic positions of certain of his colleagues regarding logic and symbols can be detected in the words:

Those who for lack of exercise regard symbolism as a liability, are not obliged to adopt it. We are building a new tool and we are not destroying the existing tools.

Peano loved freedom and democracy both in the context of research and in that of teaching. He was not an anarchic individualist, as is clear from the fact that in order to live in harmony with his colleagues he decided to turn his energies to the world of school and to the preparation of future teachers, as well as to the spread of an international language that would promote the peaceful exchange of ideas among scientists.

${ }^{50}$ G. Peano to G. Vacca, 24 April 1910: "Io abbandono l'insegnamento superiore, contro la mia volontà e con dolore. Ho fatto tutte le mie lezioni, procurando di interessare gli allievi, che si sono effettivamente interessati. Ho procurato di vivere d'accordo coi colleghi, da cui dipendo. Ma questi vogliono che io abbandoni i simboli, che non parli più del Formulario e altro ancora. Rifiutai ogni conferma in tali condizioni. Facevo quel corso per piacere e non per interesse. Così è finita. Difficilmente farò ancora uscire un volume della Rivista. Ho lavorato abbastanza, ed ho diritto di riposare, tanto più che i colleghi ritengono le mie teorie pericolose. La difesa del Formulario la faccia chi vuole. Del resto esso è un libro già abbastanza noto, e non muore più. Può essere che io dedichi questi ultimi anni all'interlingua o al giardinaggio. [... ] Io sono socio della società filosofica di Genova; mi sono iscritto con grandi idee, ma non ho più volontà di lavorare."

${ }^{51}$ Peano (1913i), 48. 


\subsection{Outcome of the Formulario and Cultural Spin-off}

It is well known that the subsequent developments of logic ${ }^{52}$ took another path, thanks above all to Russell, Hilbert and Gödel, and that Peano's Formulario was overtaken by their works. However, these authors publicly recognised their cultural debt to Peano:

M. Peano a forgé un instrument de grande puissance pour certains ordres de recherches. Quelques-uns d'entre nous s'intéressent à ces recherches, et par suite honorent M. Peano, qui est allé, selon nous, tellement plus loin et plus haut que les mathématiciens « aptères », que ceux-ci l'ont perdu de vue et ne savent pas combien il est en avance sur eux. ${ }^{53}$

On the one hand we have the works of analysts and geometers, in the way of formulating and systematising their axioms, and the work of Cantor and others on such matters as the theory of aggregates. On the other hand we have symbolic logic, which, after a necessary period of growth, has now, thanks to Peano and his followers, acquired the technical adaptability and the logical comprehensiveness that are essential to a mathematical instrument for dealing with what have hitherto been the beginnings of mathematics. ${ }^{54}$

Wie Sie bemerken, ist ein wesentliches Hilfsmittel für meine Beweistheorie die Begriffsschrift, und wir verdanken dem Klassiker dieser Begriffsschrift, Peano, die sorgfältigste Pflege und weitgehendste Ausbildung derselben. Die Form, in der ich die Begriffsschrift brauche, ist wesentlich diejenige, die Russell zuerst eingeführt hat. ${ }^{55}$

Judgments of the Formulaire by its contemporaries were mixed: flattering in Britain and in America, where Peano's symbols were adopted by some mathematicians, but harsher in France and in Italy. In 1910 Eliakim Hastings Moore proposed its introduction into mathematical analysis, printing the list of logic signs in the fifth edition of the Formulario, and Clarence Irving Lewis of the University of Berkeley stated in 1918 that the "Peano's Formulaire de Mathématiques marks a new era in the history of symbolic logic" "56. In 1971 Kurt Gödel suggested to Ralph Hwastecki to use the Peano's Formulaire with the students ${ }^{57}$.

In France and in Italia the Formulario was involved in the controversy on intuition and rigour, which flared up between 1905 and 1907 in the pages of the Revue de metaphysique et de morale, with echoes in the Italian journal Leonardo. The debate was wide-ranging and well-expressed and involved mathematicians and

${ }^{52}$ Cf. Cellucci (1993), 73-138.

${ }^{53}$ B. Russell (1906), 628. Cf. also B. Russell (1917). The influence of the Formulario on Russell is well documented in F.A. Rodriguez-Consuegra (1991), 91-165, 175-177, 181-184.

${ }^{54}$ A.N. Whitehead, B. Russell (1910); also C.I. Lewis (1918), 115.

${ }^{55}$ D. Hilbert (1929), 137.

${ }^{56}$ C.I. Lewis (1918), 115; also 278-281.

${ }^{57}$ Cf. S. Feferman, J.W. Dawson Jr., W. Goldfarb, Ch. Parsons, W. Sieg (eds.) The Collected Works of Kurt Gödel, vol. V Correspondence H-Z, Oxford, University Press, 2003, 80-81. 
philosophers of the calibre of H. Poincaré, B. Russell, A.N. Whitehead, L. Couturat, E. Borel, M. Winter, G. Peano, G. Vacca, G. Vailati, M. Pieri and B. Croce.

The emergence of the antinomies of the theory of sets and the doubts regarding the axiom of choice - subjects which had had great resonance after the publication of the famous Cinq lettres sur la théorie des ensembles by R. Baire, E. Borel, H. Lebesgue and J. Hadamard - contributed to attract attention to the relationships between logic and mathematics and on the usefulness of the former in the latter. Faced by the proliferation of paradoxes, harsh criticisms were moved against the symbolic logic of Peano, Russell and Hilbert, accused of hindering the momentum of intuition and creativity and of not safeguarding the theories of vicious circles. What in Francia proved harmful to the reception of the Formulario was the action of the philosopher Couturat, who presented it with excessive emphasis as a work destined to carry out the refoundation of the logic of all mathematics, misunderastanding its more modest didactic range. Thus he finally provoked the caustic irony of Poincaré who, secure in his scientific and academic prestige, announced his refusal to read the Formulario and challenged the experts in logic to use the wings of symbolism to take flight towards the construction of new theories:

En ce qui concerne la fécondité, il semble que L. Couturat se fasse de naïves illusions. La logistique d'après lui, prête à l'invention « des échasses et des ailes » et à la page suivante : «il y a dix ans que M. Peano a publié la première édition de son Formulaire. » Comment, voilà dix ans que vous avez des ailes, et vous n'avez pas encore volé ! J'ai la plus grande estime pour M. Peano qui a fait des très jolies choses (par exemple sa courbe qui remplit toute une aire); mais enfin il est allé ni plus loin, ni plus haut, ni plus vite que la plupart des mathématiciens aptères, et il aurait pu faire tout aussi bien avec ses jambes. ${ }^{58}$

Though severe and heated, the controversy was not a sterile debate, but laid the foundations for a dialogue between mathematicians and philosophers on logicofoundational topics, rare in other European countries and very superficial in Italy. This bore fruit in original results. Among these may be citated the studies on compatibility, the independence and logical irreducibility of the axioms of arithmetic, conducted by Pieri and by Padoa between 1906 and 1912, the simplifications of Cantor-Bernstein's theorem, thanks to Peano and to Padoa, the theory of types developed by Russell to overcome the obstacle of the antinomies and the distinction between logical and semantic paradoxes introduced by Ramsey, following the brief mention by Peano in the note Super theorema de Cantor Bernstein ${ }^{59}$.

In Italy the main cultural spin-off of the operation carried out by Peano in the Formulario can be seen in the encyclopaedic collections, edited by F. Enriques and by Berzolari, Vivanti and Gigli, and in the dozens of texts for upper schools written by members of the School of Peano. The encyclopaedias of elementary mathematics were prepared by a team of mathematical researchers, some of whom had collabo-

\footnotetext{
${ }^{58}$ H. Poincaré (1906), 295.

59 M. Pieri (1906d), 196-207; (1908b), 26-30 - Opere..., Roma, 1980, 449-453; G. Peano (1906b), 360-366; (1906e), 143-157; B. Russell (1906), 627-650; A. Padoa (1911), (1912); F. Ramsey (1925), 338-384.
} 
rated on the Formulario. A certain importance here can be attributed to the history of mathematical ideas, of concepts, of theorems, of methods and of theories. The chapter on mathematical logic for Enriques' Encyclopaedia was requested of Padoa, the one on History of Vacca, though it was not finally entrusted to him.

The manuals on arithmetic, geometry and analysis for middle schools, written by the teachers of Peano's group, demonstrate the absorption of those criteria of rigour, simplicity and essentiality in the transmission of knowledge, typical of the Formulario. The insertion of the content in a historical context which justified its choices, and the attempt to avoid excessive, cold symbolism, had positive effects for the spread of the theories on the foundations of arithmetic and of geometry However, for Peano and for his principal followers the Formulaire always remained the most meritorious work they had carried out in mathematics ${ }^{60}$. At the ripe age of 70, in 1929, Peano proposed a new edition to the President of the Mathematical Committee of the Research Council:

A collective task which can be carried out is the publication of a new edition of the Formulario matematico, whose fifth and last edition of 1908 has sold out. This Formulario is a mathematical encyclopaedia, or collection of all the mathematical propositions written in symbol, with their proof and history. The use of symbols offers the primary advantage of brevity; in addition, many propositions which in ordinary language appear to be distinct, prove to be identical; and the propositions take on a precise form, much more than with ordinary language. Prof. Cipolla of Palermo writes to me: "I consider it very timely, indeed necessary, to publish a new edition of the Formulario." And Profs. Boggio of Turin, Cassina of Milan, Padoa of Genoa and many others are in favour of its continuation. The language used in the last edition is Latinsine-flexione, very useful to make the work known abroad offering greater diffusion, both to express the ideas more clearly, not confused by grammatical inflexions. The history is made up of passages taken from the authors, in the original form and language. [...] I should be glad to dedicate the rest of my life to it, now I am in my seventies. ${ }^{61}$

${ }^{60}$ Cf. U. Cassina (1933), 323-389 and G. Vacca (1946), 30-44.

${ }^{61}$ G. Peano to G. Scorza, Torino 24 February 1929, in C.S. Roero, N. Nervo, T. Armano (2002): "Un lavoro collettivo che si può fare è la pubblicazione di una nuova edizione del Formulario matematico, di cui la quinta ed ultima edizione del 1908 è ora esaurita. Questo Formulario è una enciclopedia matematica, o raccolta di tutte le proposizioni matematiche scritte in simboli, colla dimostrazione e storia. L'uso dei simboli offre il primo vantaggio della brevità; inoltre molte proposizioni che col linguaggio comune paiono distinte, si rivelano identiche; e le proposizioni assumono una forma precisa, molto più che col linguaggio comune. Il prof. Cipolla di Palermo mi scrive: 'Ritengo opportunissima, anzi necessaria la pubblicazione di una nuova edizione del Formulario.' E sono in caso di continuarlo i proff. Boggio di Torino, Cassina di Milano, Padoa di Genova e molti altri. La lingua usata nell'ultima edizione è il Latino-sine-flexione, molto utile per far conoscere il lavoro all'estero dandoci maggior diffusione, sia per esprimere le idee in modo più chiaramente, non confuse dalle flessioni grammaticali. La storia è fatta riportando i passi degli autori, nella lingua e forma originale [... ] io sarei lieto di dedicare ad esso il restante della mia vita, dopo gli anni settanta." 
As for Leibniz, so for Peano the mathematical encyclopaedia written in symbols remained a Utopian dream, as he succeeded in completing only the part regarding elementary and classical mathematics. In this sense his enterprise stands side by side with the series of encyclopaedias of elementary mathematics, which were issued in his own time. Peano's dream of a work collecting all mathematical research, even the most advanced, was to find the worthy fulfilment of his initial ideals only in the 20 th century, in the Bourbaki group ${ }^{62}$. Peano had scattered the first seeds for the immense undertaking which was then presented by the Bourbaki group: advanced mathematics, expounded in abstract, symbolic mode, and accompanied by the historical context of the most important stages in the various branches of research. What they wrote in 1960 is a tribute to Peano:

Le but de Peano était à la fois plus vaste et plus terre à terre [Frege]; il s'agissait de publier un Formulaire de mathématiques, écrit entièrement en langage formalisé et contenant non seulement la logique mathématique, mais tous les résultats des branches des mathématiques les plus importantes. La rapidité avec laquelle il parvint à réaliser cet ambitieux projet, aidé d'une pléiade de collaborateurs enthousiastes (Vailati, Pieri, Padoa, Vacca, Vivanti, Fano, Burali-Forti) témoigne de l'excellence du symbolisme qu'il avait adopté : suivant de près la pratique courante des mathématiciens, et introduisant de nombreux symboles abréviateurs bien choisis, son langage reste en outre assez aisément lisible, grâce notamment à un ingénieux système de remplacement des parenthèses par des points de séparation. ${ }^{63}$

Of importance, too, is the fact that they recognised that certain criticisms from Poincaré were exaggerated and unjust; these criticisms had contributed to hinder the spread of the Formulaire in France:

Bien des notations dues à Peano sont aujourd'hui adoptées par la plupart des mathématiciens : citons $\in, \supset$ (mais, contrairement à l'usage actuel, au sens de est contenu ou implique), $\cup, \cap, \mathrm{A}-\mathrm{B}$ (ensemble des différences $a-b$, où $a \in \mathrm{A}$ et $b \in \mathrm{B}$ ). D'autre part, c'est dans le Formulaire qu'on trouve pour la première fois une analyse poussée de la notion générale de fonction [...]. Mais la quantification, chez Peano, est soumise à des restrictions gênantes [...]. En outre le zèle presque fanatique de certains de ses disciples prêtait aisément le flanc au ridicule ; la critique, souvent injuste, de Poincaré en particulier, porta un coup sensible à l'école de Peano et fit obstacle à la diffusion de ses doctrines dans le monde mathématique. Avec Frege et Peano sont acquis les éléments essentiels des langages formalisés utilisés aujourd'hui. Le plus répandu est sans doute celui forgé par Russell et Whitehead dans leur grand ouvrage Principia Mathematica, qui associe heureusement la précision de Frege et la commodité de Peano. ${ }^{64}$

\footnotetext{
${ }^{62}$ B. Segre (1955), 31-39.

${ }^{63}$ N. Bourbaki (1960), 20-21; (1970), Structures Note historique E IV 42.

${ }^{64} \mathrm{~N}$. Bourbaki (1960), 21.
} 
In Italy certain of the protagonists of active mathematical research, such as Volterra and Enriques, were somewhat disdainful of the work carried out by Peano in the Formulario, stressing above all its philosophical aspect. In 1908 at the international congress of mathematicians, which was held in Rome, Volterra expressed the following judgment of the progress made in the second half of the 19th century, in particular in the field of analysis:

Research on the functions of real variables and their singularities, which were called the studies on the deformities and monstrosities of mathematics, in which the aid of the so-called physiological laws of geometry are missing, and not only is every intuition lacking, but all the simple persuasive forecasts most of the time lead to error. [... ] It was Dini who introduced and spread in Italy the passion for this research with his works, and even more, with his effective and original teaching. [...] Weierstrass and Riemann, moving from ideas which had somewhat infiltrated into analysis, had begun them, Georg Cantor had astonished everyone with his unexpected revelations, Du Bois-Reymond had penetrated many obscure problems and Darboux had discovered many fine, original propositions. Dini, coordinating this set of doctrines, enriching them with new truths, had the courage to bring them to Italy in school at the very beginning of the studies in infinitesimal analysis and as their basis. [...] Attracted by these studies, a school was formed in Italy of mathematicians who dedicated the energies of their genius to the development of these doctrines and brought about important results. And the studies themselves took on a double direction among us: one led Ascoli, Arzelà and others to concrete research on the series, the limits and the theory of functions; the other, with Peano and the School that took its inspiration from him, aimed to give an increasingly solid basis to the fundamental concepts, merged with those doctrines that were going more deeply into the criticism of the postulates and drove on from day to day into ever more abstract regions, taking on a more philosophical aspect. ${ }^{65}$

${ }^{65}$ V. Volterra (1909), 62: “[...] ricerche sopra le funzioni di variabili reali e le più riposte singolarità loro, che efficacemente furon chiamate gli studi sulle deformità e le mostruosità della matematica, in cui l'aiuto delle leggi, per dir così, fisiologiche della geometria viene a mancare, e non solo ogni intuizione fa difetto, ma tutte le facili e seducenti previsioni inducono il più spesso in errore. [...] Fu il Dini che introdusse e diffuse in Italia l'amore per queste ricerche colle sue opere, e più ancora, con l'efficace ed originale suo insegnamento. [...] Weierstrass e Riemann, movendo da idee che si erano un poco alla volta infiltrate nell'analisi, le avevano iniziate, Giorgio Cantor aveva fatto strabiliar tutti colle sue inattese rivelazioni, il Du Bois-Reymond era penetrato addentro a molti oscuri problemi ed il Darboux aveva scoperto tante belle ed originali proposizioni. Il Dini, coordinando questo insieme di dottrine, arricchendole di nuove verità ebbe il coraggio di portarle in Italia nella scuola all'inizio stesso degli studi di analisi infinitesimale e come base di essi. [...] Attratta da questi studi, si formò in Italia una scuola di matematici che consacrarono le forze del loro ingegno allo sviluppo di queste dottrine ed apportarono loro importanti risultati. E presero gli studi stessi doppia direzione fra noi: l'una condusse l'Ascoli, l'Arzelà ed altri a ricerche concrete sopra le serie, i limiti e la teoria delle funzioni; l'altra mirò, col Peano e colla Scuola che ebbe l'impulso da lui, a dare una base sempre più solida ai concetti fondamentali, si fuse con quelle dottrine che approfondivano la critica dei postulati e si spinse di giorno in giorno in regioni sempre più astratte, acquistando un carattere vieppiù filosofico.” Cf. also F. Enriques (1913), 77. 
The way in which Peano did research in the Formulario was a long way from, almost antithetical to that of Poincaré and of Volterra, in that it looked more to the past than to the future, more directed at the codification and structuring of theories that had already been learned, rather than at the conception and development of new branches of mathematics. One of Peano's best and most enthusiastic collaborators, Mario Pieri, was able to grasp this 'static' aspect at the basis of the logical research to be found in the Formulario and characteristic of the style of the Piedmontese scholar, observing shrewdly that:

The direct and immediate discovery by way of brilliant intuition, the artistic divination, will always have great status and power in the kingdom of knowledge: but opposing the fact of invention to the progress of demonstrative Logic would be like denying faith and value to counterpoint out of respect for musical inspiration. [...] Not sufficient distinction is made (I believe) between science and art, between the static and rational structure of a scientific discipline and its operative and dynamic qualities. The tendencies of logistics (it should be recognised) aim more at the static equilibrium of the various deductive disciplines and at science, as a body of established truths, than at the operative function of the scientific discovery. ${ }^{66}$

For his part, Peano had become further convinced that by means of the education of the young in the clear, simple, rigorous exposition of mathematics, through the use of logic, there would be an improvement in Italy of school and also research would take on new drive. At the lemma "Logica matematica" in the Dizionario di cognizioni utili in 1919, he insisted on precisely this point:

With these ten or twelve symbols, together with the symbols to represent the ideas of arithmetic and of geometry, all the propositions of mathematics can be expressed, as can be seen in Peano's Formulario mathematico. With this tool analysis has been made of the definition encountered in mathematical texts, and it has been found that they satisfy special rules, never before expressed. Analysis has been made of the forms of reasoning used in mathematical proofs, and it has been seen that they are not reduced to the types considered in the treatises on logic. We have found what are the primitive ideas of arithmetic and of geometry, especially by the work of the late lamented Pieri; the principles of mathematics have been analysed, at the hands especially of Russell and Whitehead. This tool was useful to Moore for the integration of

\footnotetext{
${ }^{66}$ M. Pieri (1906-07), 60: "La scoperta diretta e immediata per intuizione geniale, la divinazione artistica, avranno sempre grande stato e potere nel regno della conoscenza: ma opporre il fatto dell'invenzione ai progressi della Logica dimostrativa sarebbe come negar fede e valore al contrappunto in ossequio all'ispirazione musicale. ... Non si distingue abbastanza (io credo) fra scienza ed arte, fra l'assetto statico e razionale di una disciplina scientifica e le sue qualità operative e dinamiche. Le tendenze logistiche (conviene riconoscerlo) mirano più all'equilibrio statico delle varie discipline deduttive e alla scienza, come corpo di verità stabilite, che alla funzione operativa della scoperta scientifica."
} 
differential equations. Some school books are already formed on mathematical logic, and it is in the field of teaching that this science can prove its dazzling simplicity. ${ }^{67}$

Simplicity, brevity and rigour were the pivotal elements of Peano's mathematics. His most famous results arose as he was preparing his university lectures and reading the works of the great mathematicians of the past. The Formulario was none other than the distillation of the disciplines with which he dealt in his university courses, expounded in symbolic manner, and linked to their history. The value of the exposition condensed in symbols was intended to permit dialogue among specialists in several different sectors of mathematics and the young researchers would thus be able more readily to have command of a field which was becoming ever more extensive. Hence it is not strange that Peano should have written to that "Out of a book by Lebesgue there may be one line, or half a page." Just as for Joseph Joubert, for Peano too the summit of art lies in "Concentrating a page in one line, and a line in one word."

Acknowledgements I wish to thank Erika Luciano for interesting conversations on the use of the Formulario in Peano's university lectures and in his research on mathematical Analysis, prompted by her doctoral thesis. I am also grateful to Helène Gispert, Gabriele Lolli, Enrico Pasini, Flavio Previale, Renau d'Enfert, Livia Giacardi and Roberto Vacca for indicating texts which facilitated my research, and Giuliano Moreschi, Laura Garbolino, Giuseppe Semeraro and Renzo Vienna for their helpfulness in obtaining bibliographical materials in the libraries in which they work.

${ }^{67}$ G. Peano (1919e), 960: "Con questa decina di simboli, uniti ai simboli per rappresentare le idee di aritmetica e di geometria, si possono esprimere tutte le proposizioni di matematica, come si può vedere nel Formulario mathematico di Peano. Con questo strumento si sono analizzate le definizioni che si incontrano nei libri di matematica, e si è trovato che esse soddisfano a regole speciali, non enunciate prima. Si sono analizzate le forme di ragionamento usate nelle dimostrazioni matematiche, e si è visto che esse non si riducono ai tipi considerati nei trattati di logica. Si è trovato quali sono le idee primitive dell'aritmetica e della geometria, per opera specialmente del compianto Pieri; si sono analizzati i principi della matematica, per opera specialmente di Russell e Whitehead. Questo strumento servì a Moore per l'integrazione di equazioni differenziali. Già alcuni libri scolastici sono formati sulla logica matematica, ed è nel campo dell'insegnamento che questa scienza può dimostrare la sua fulgida semplicità." 


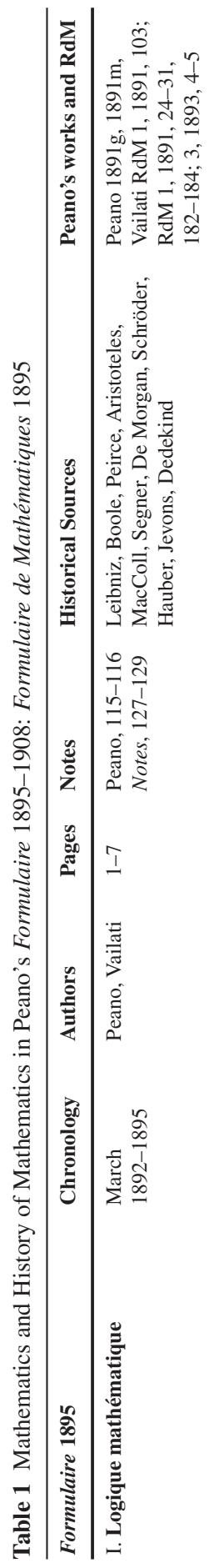

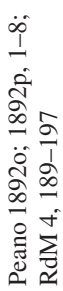
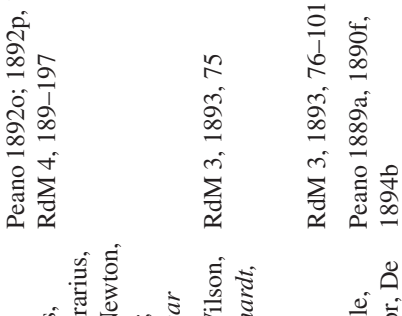

站

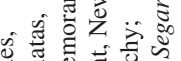

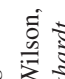

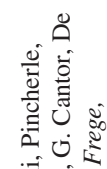

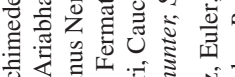

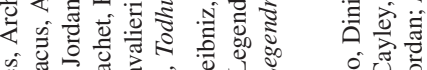

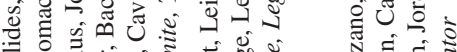

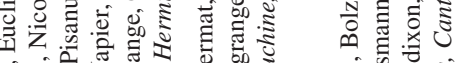

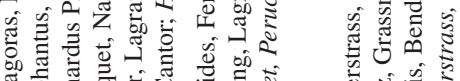

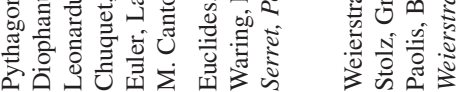

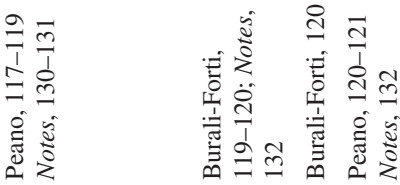

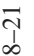

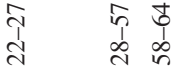

章

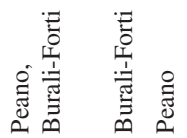

尝

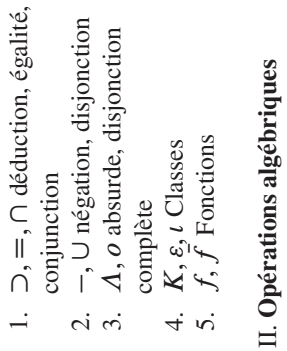

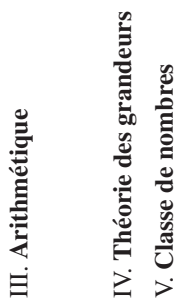




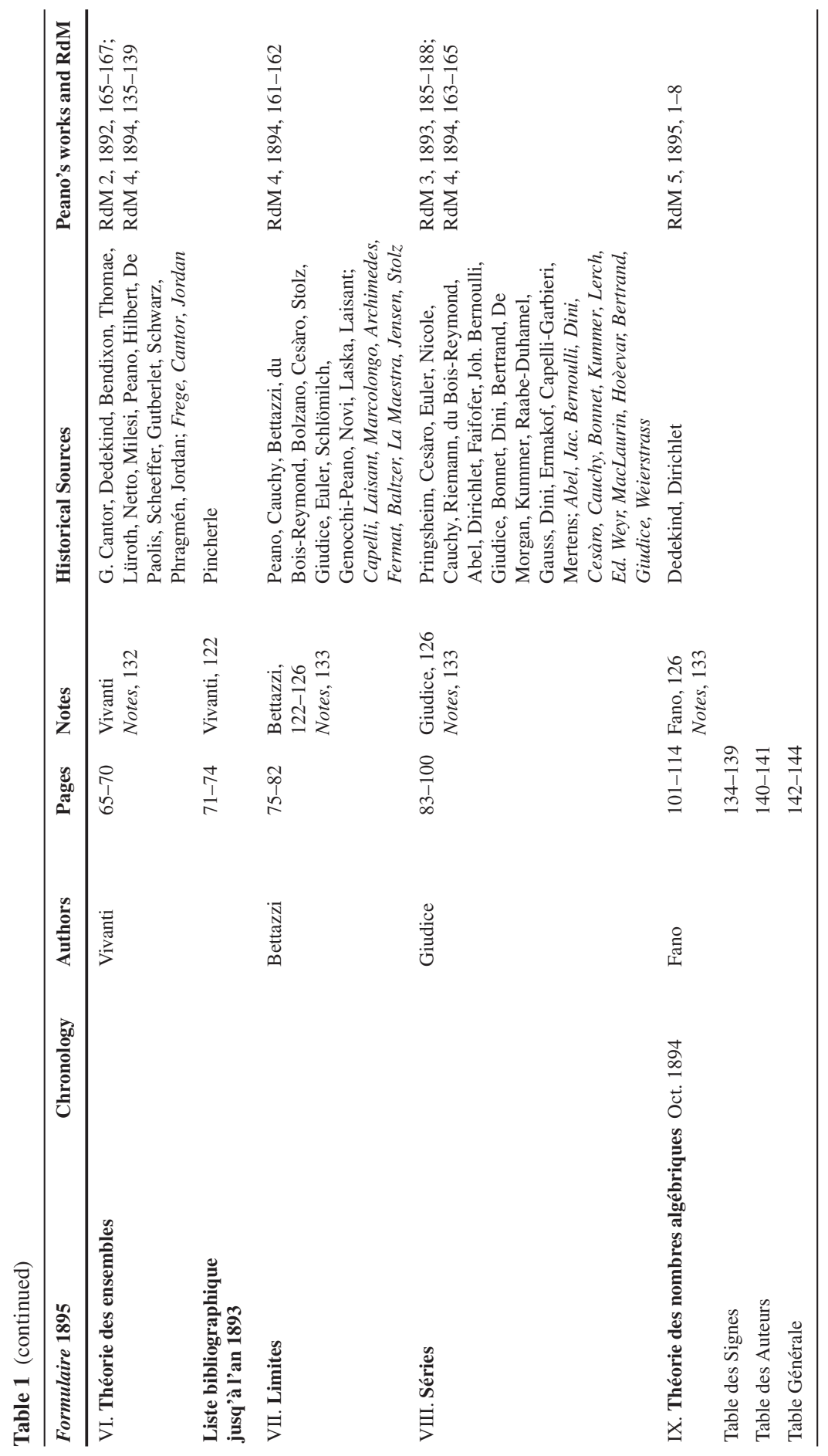




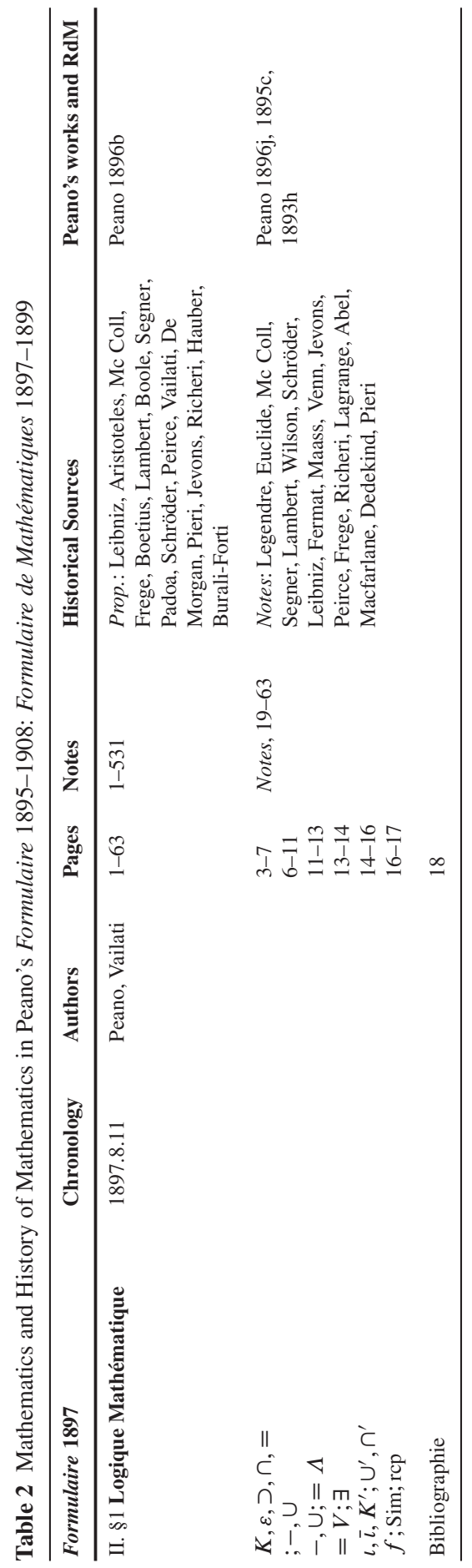




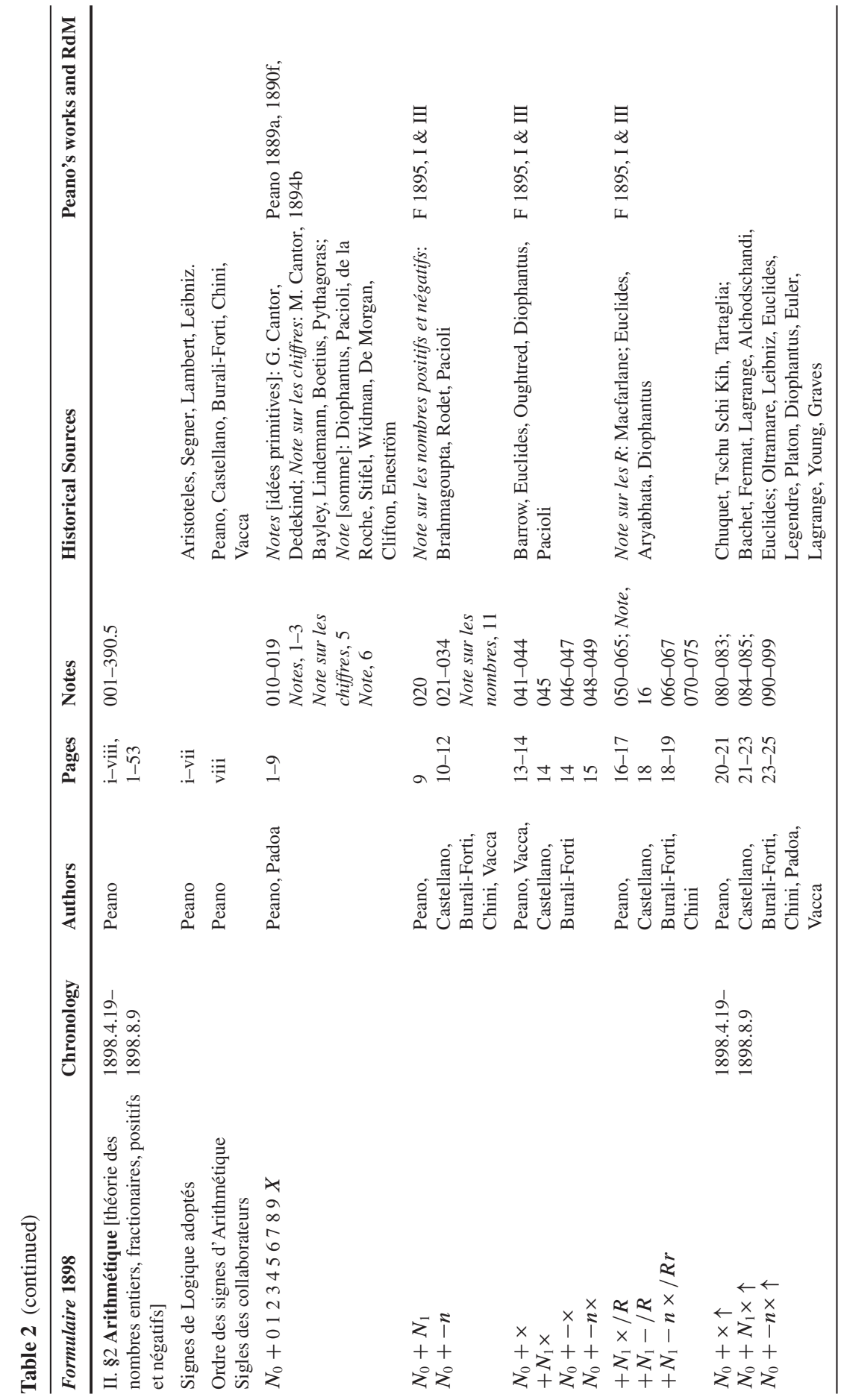




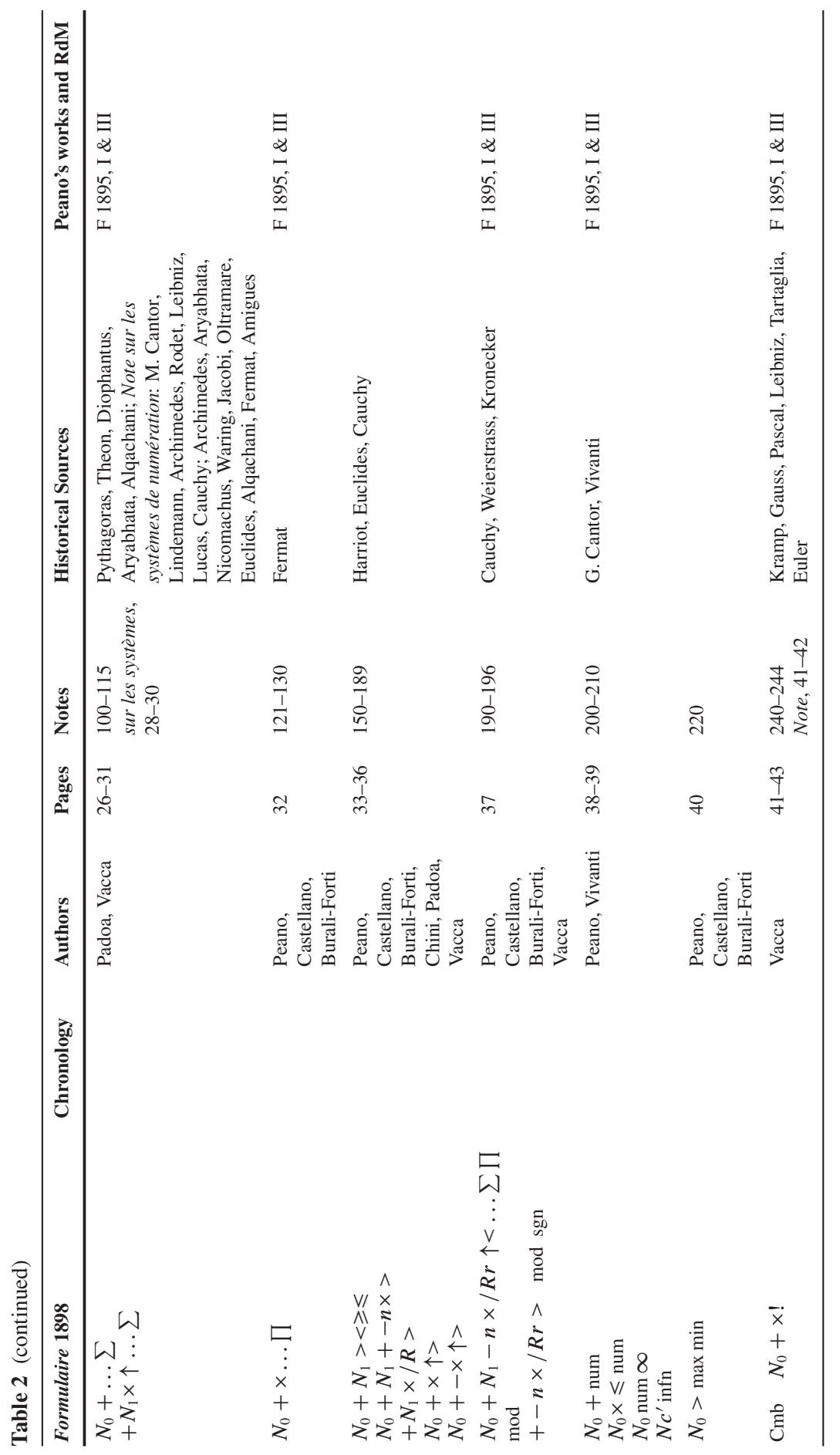




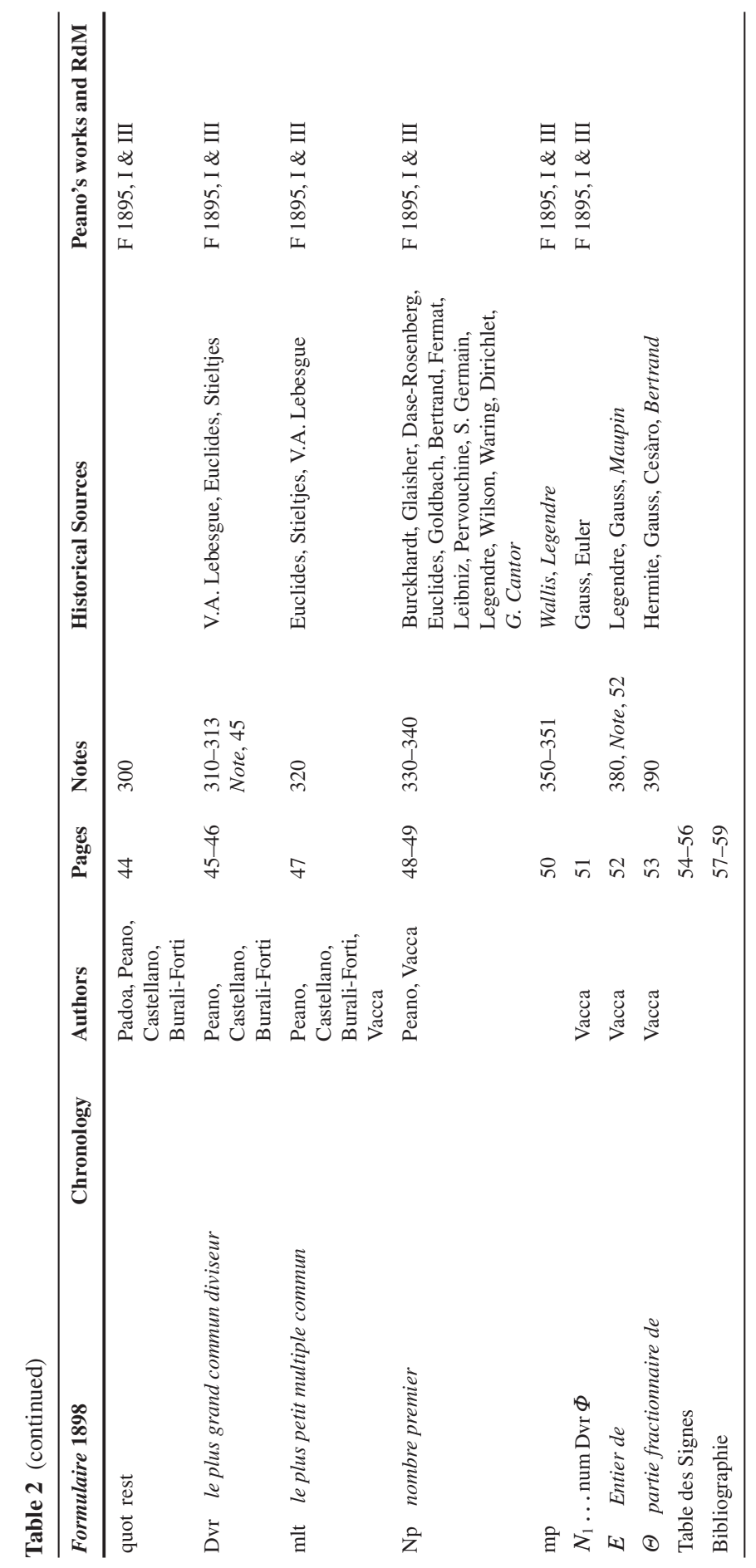




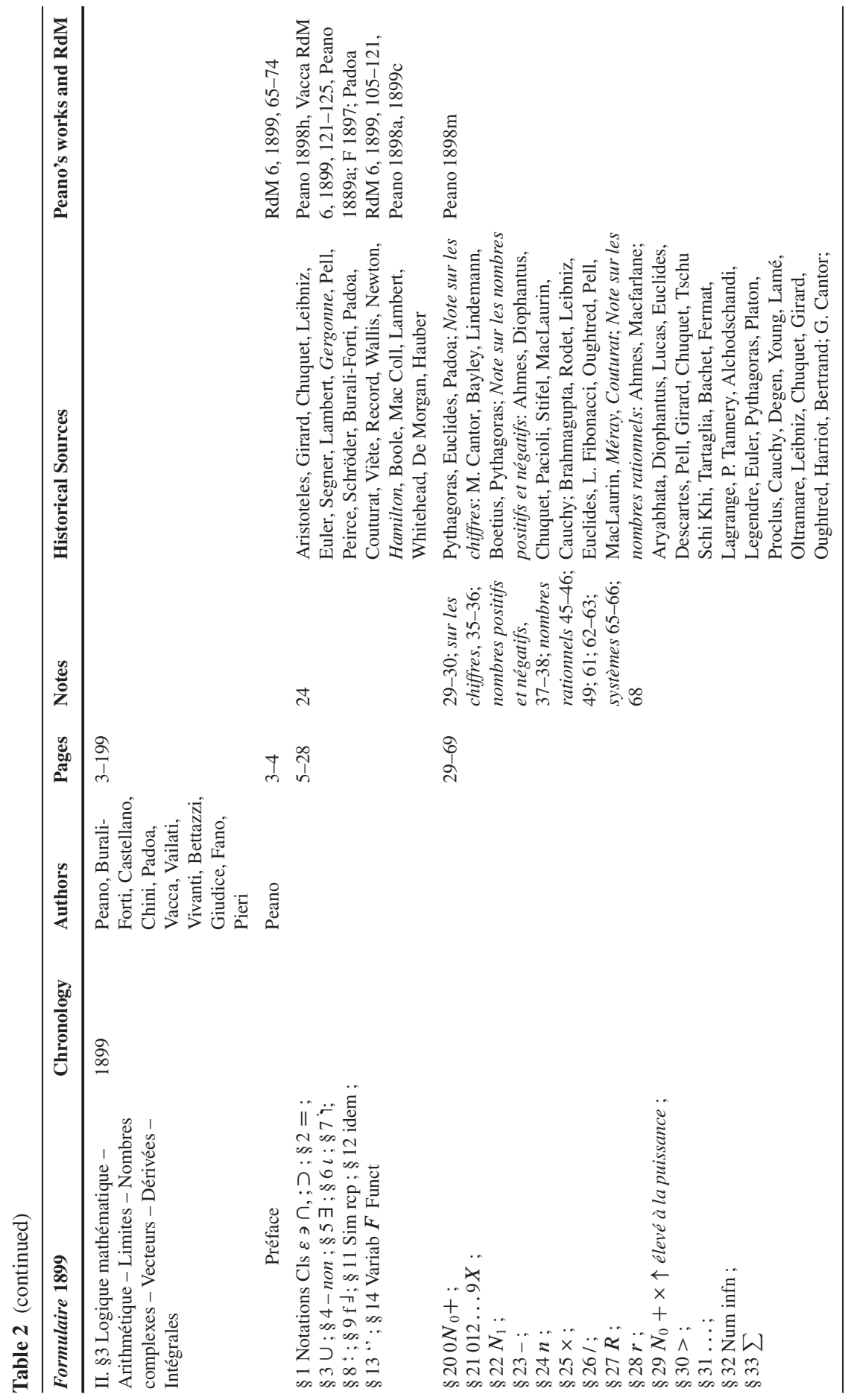




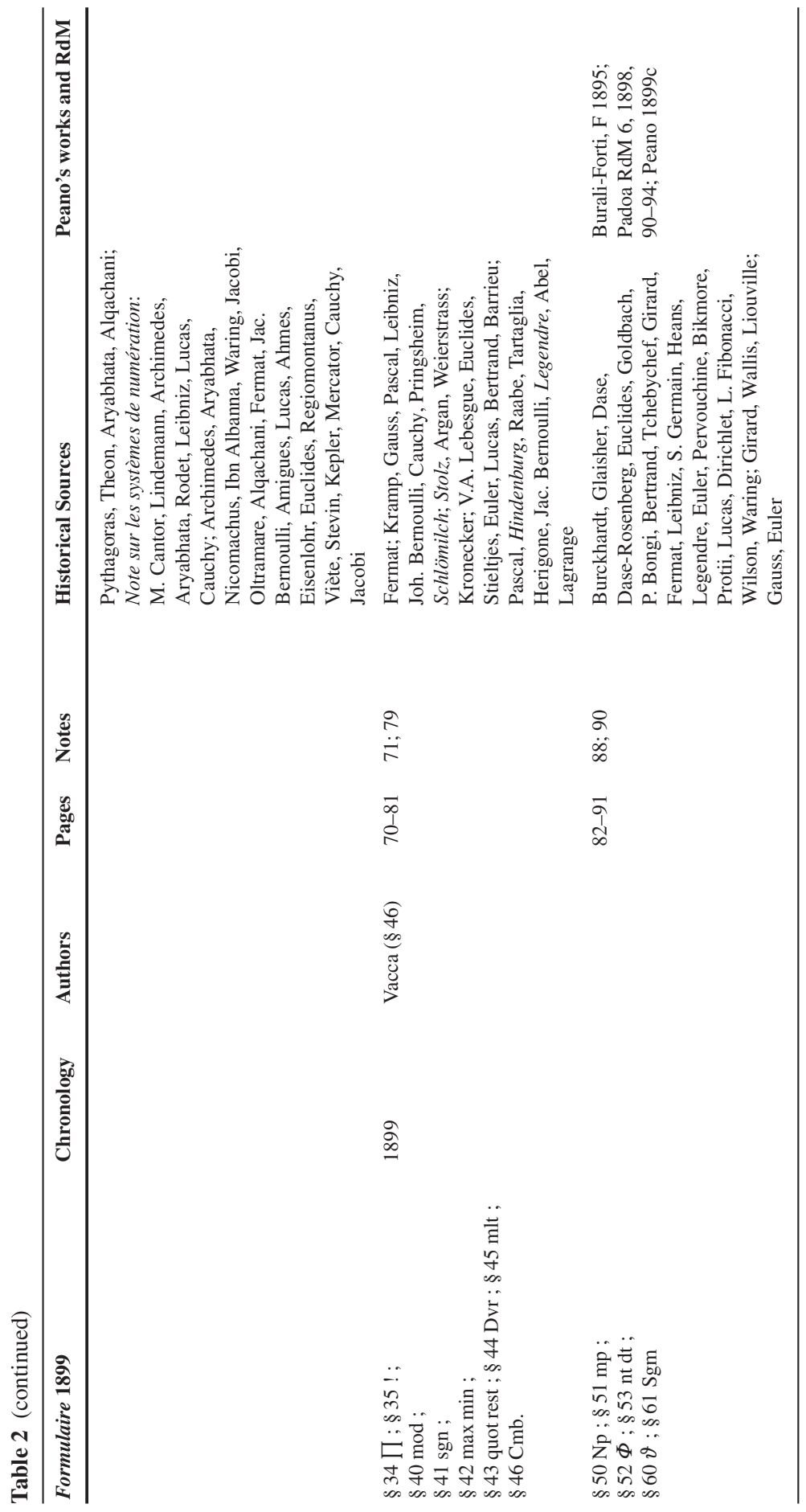



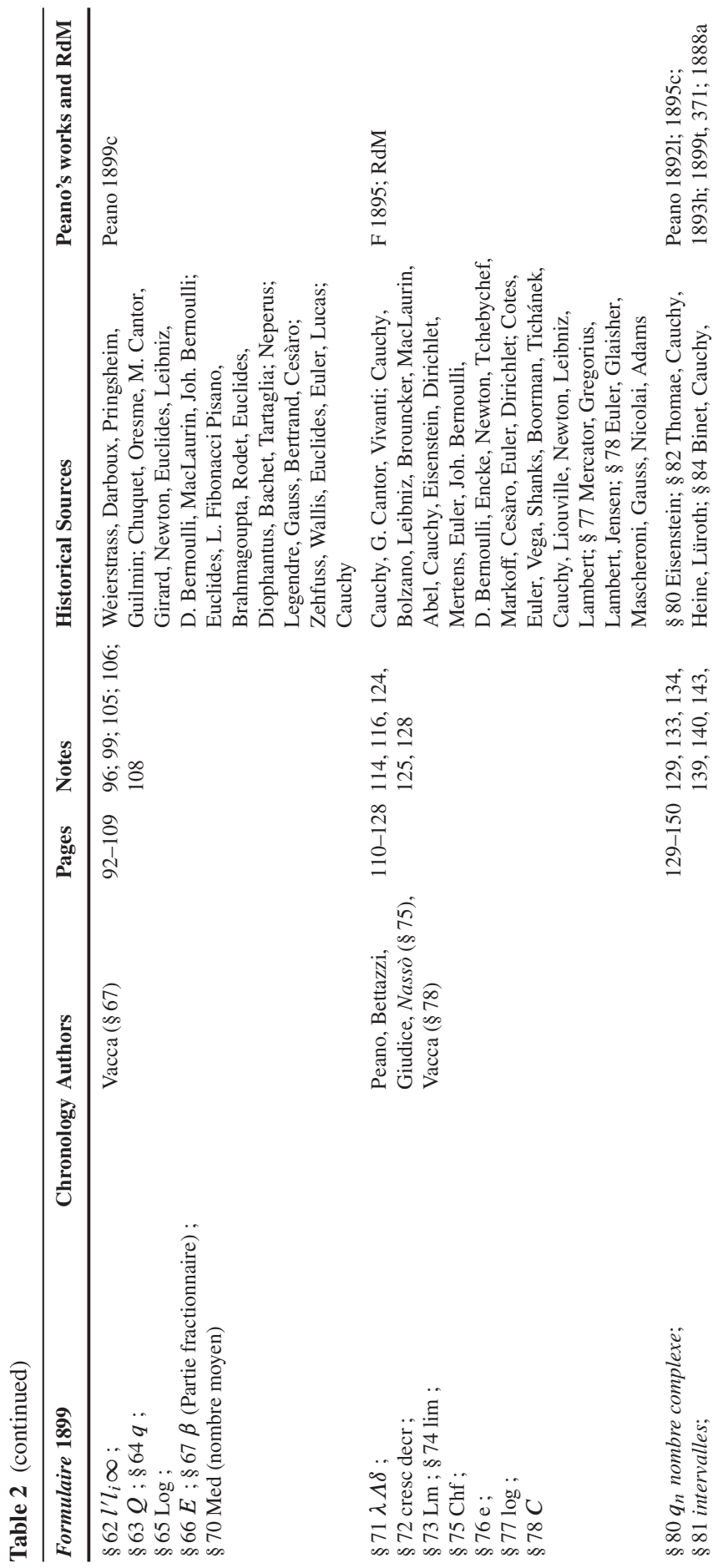

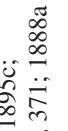
苟高
올

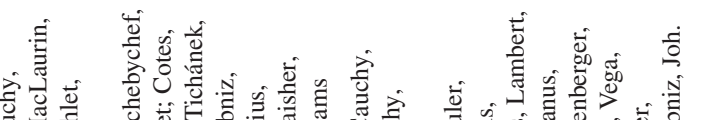

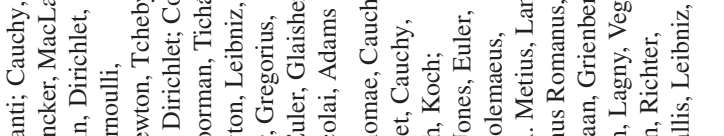

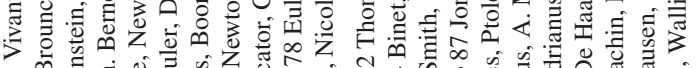

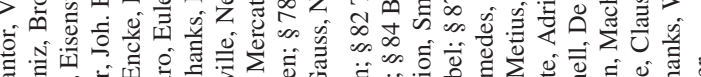

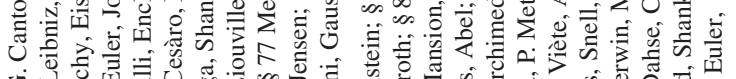
ט.

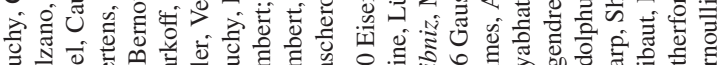

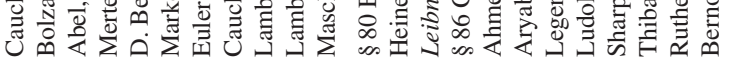

ปี

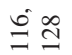

ปี่

$\stackrel{\infty}{\sim}$

ఏ

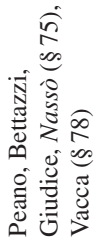

กิ

लें

จิ ภิ่

을

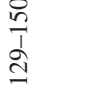

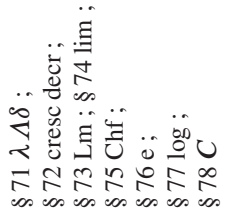

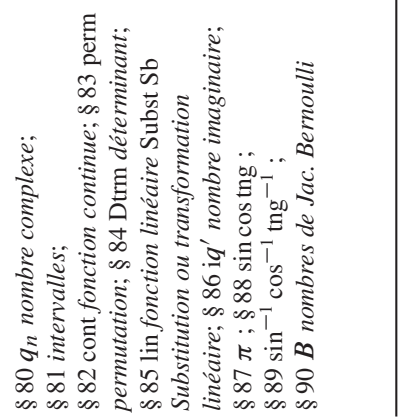




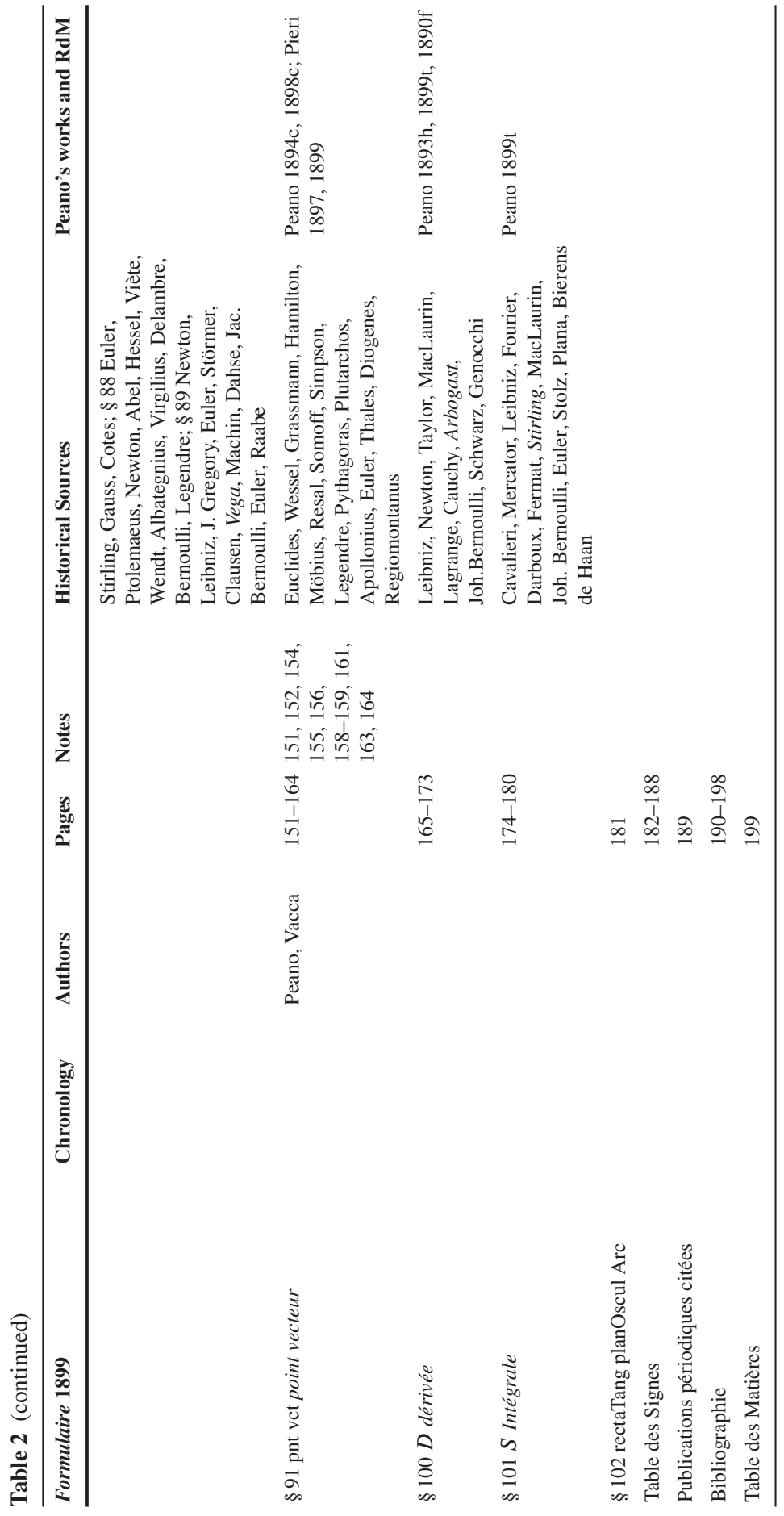




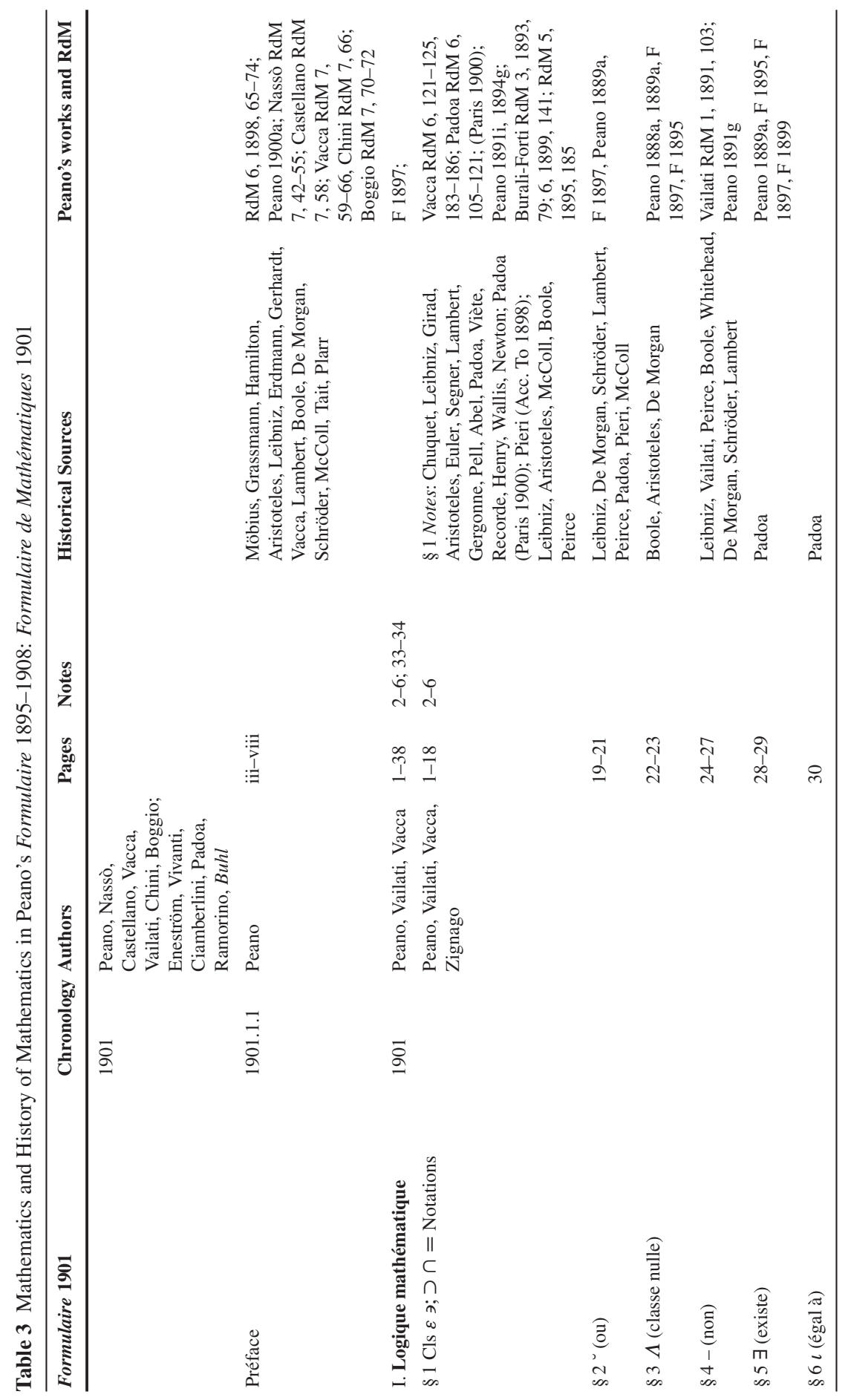




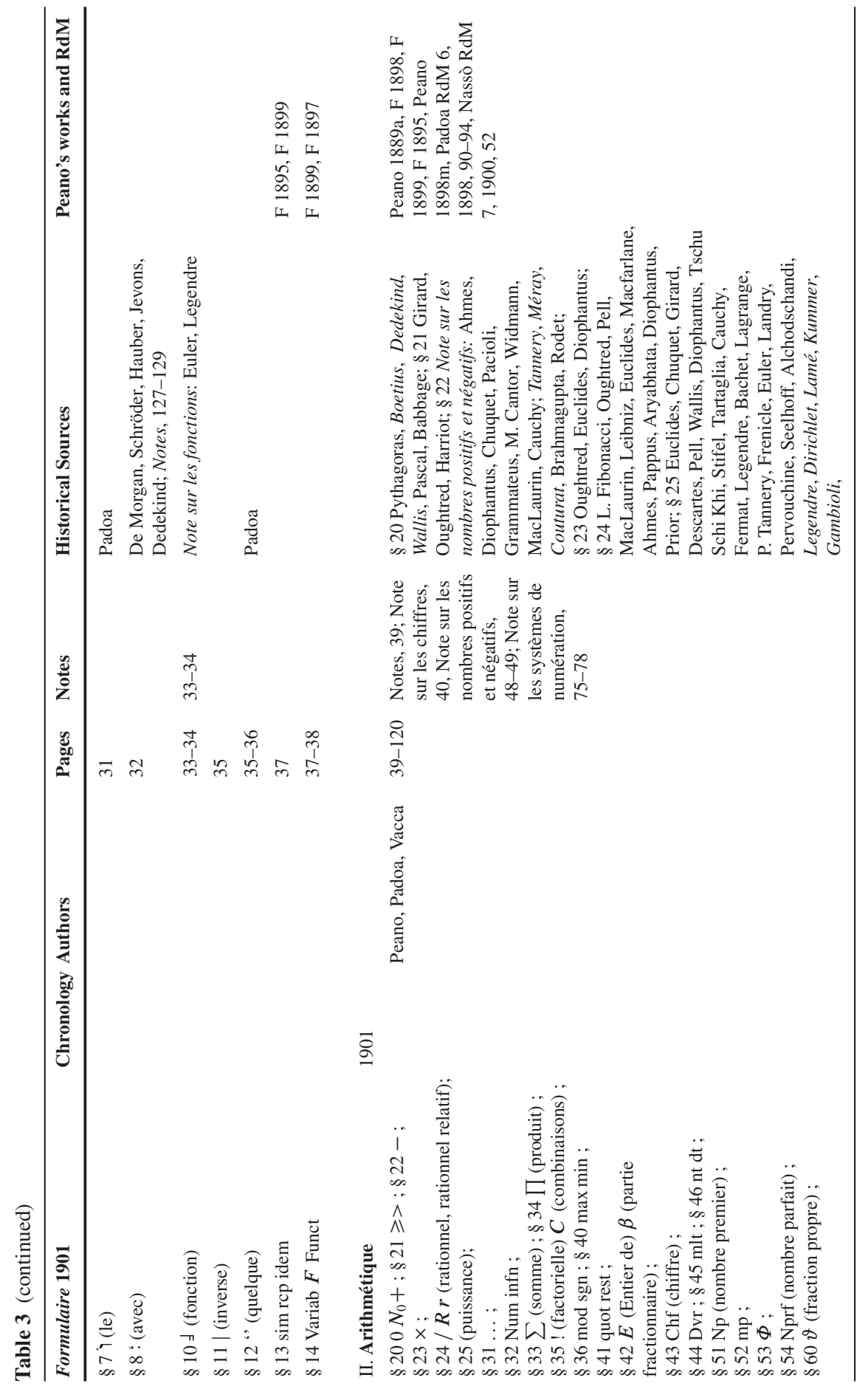




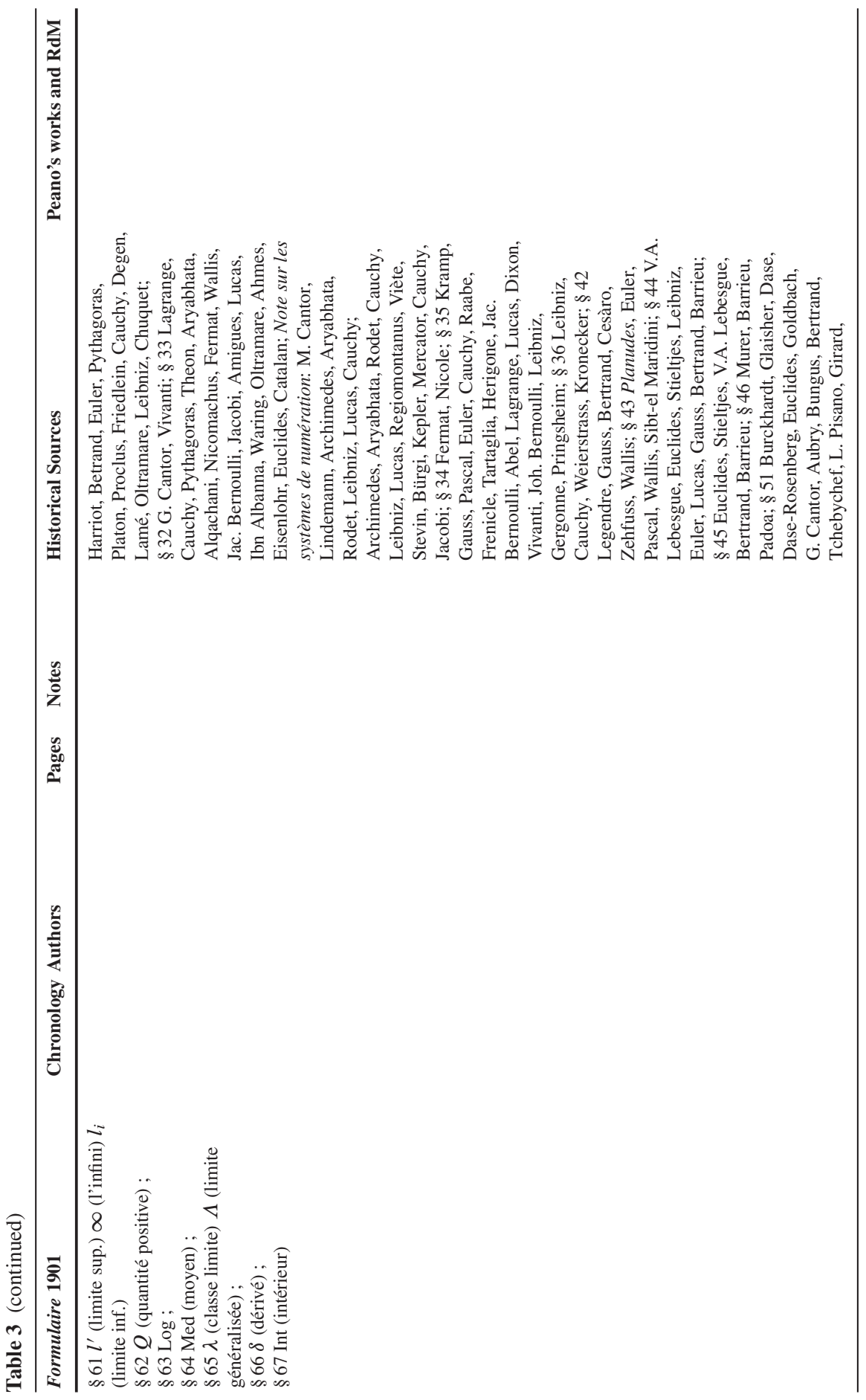




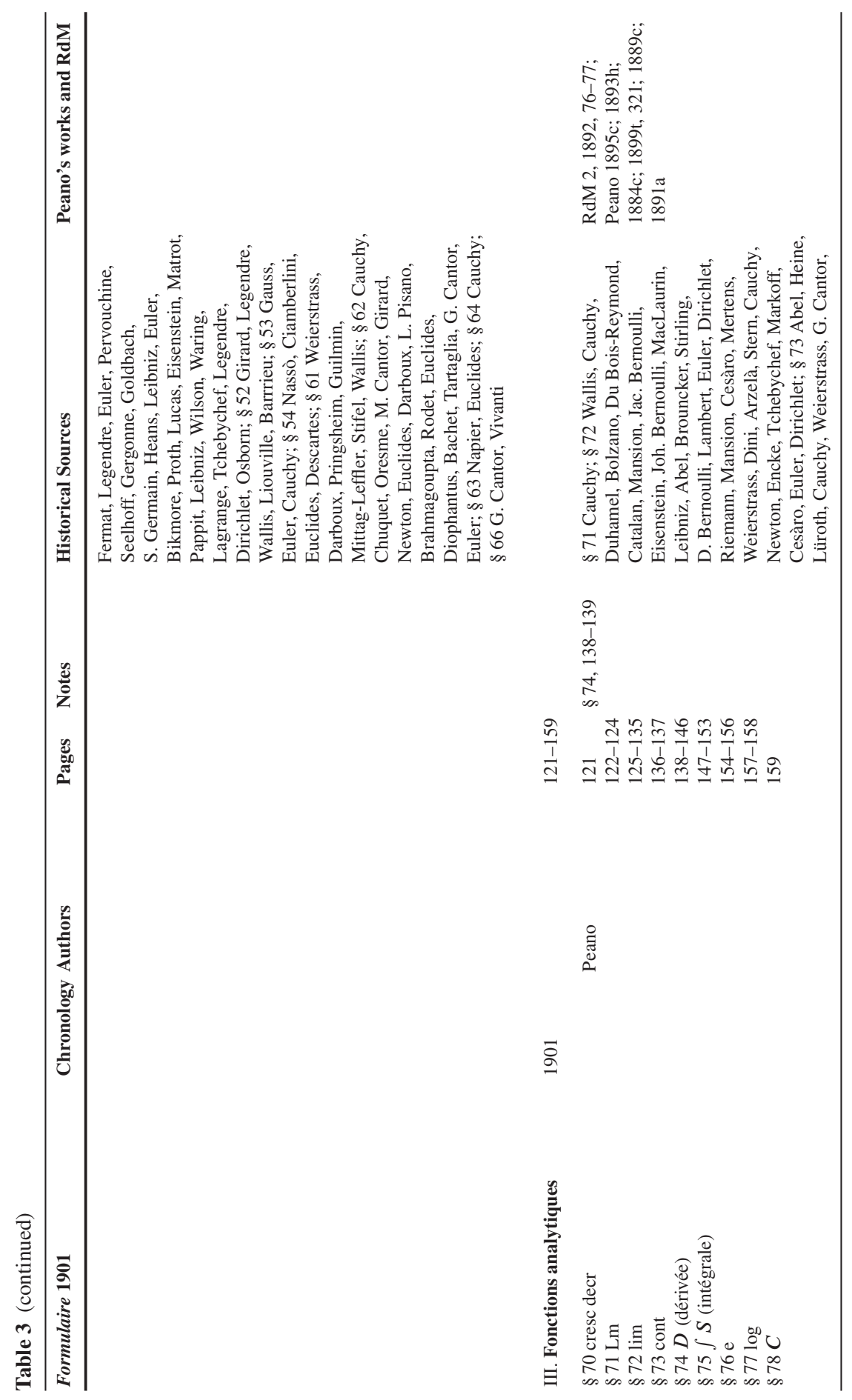




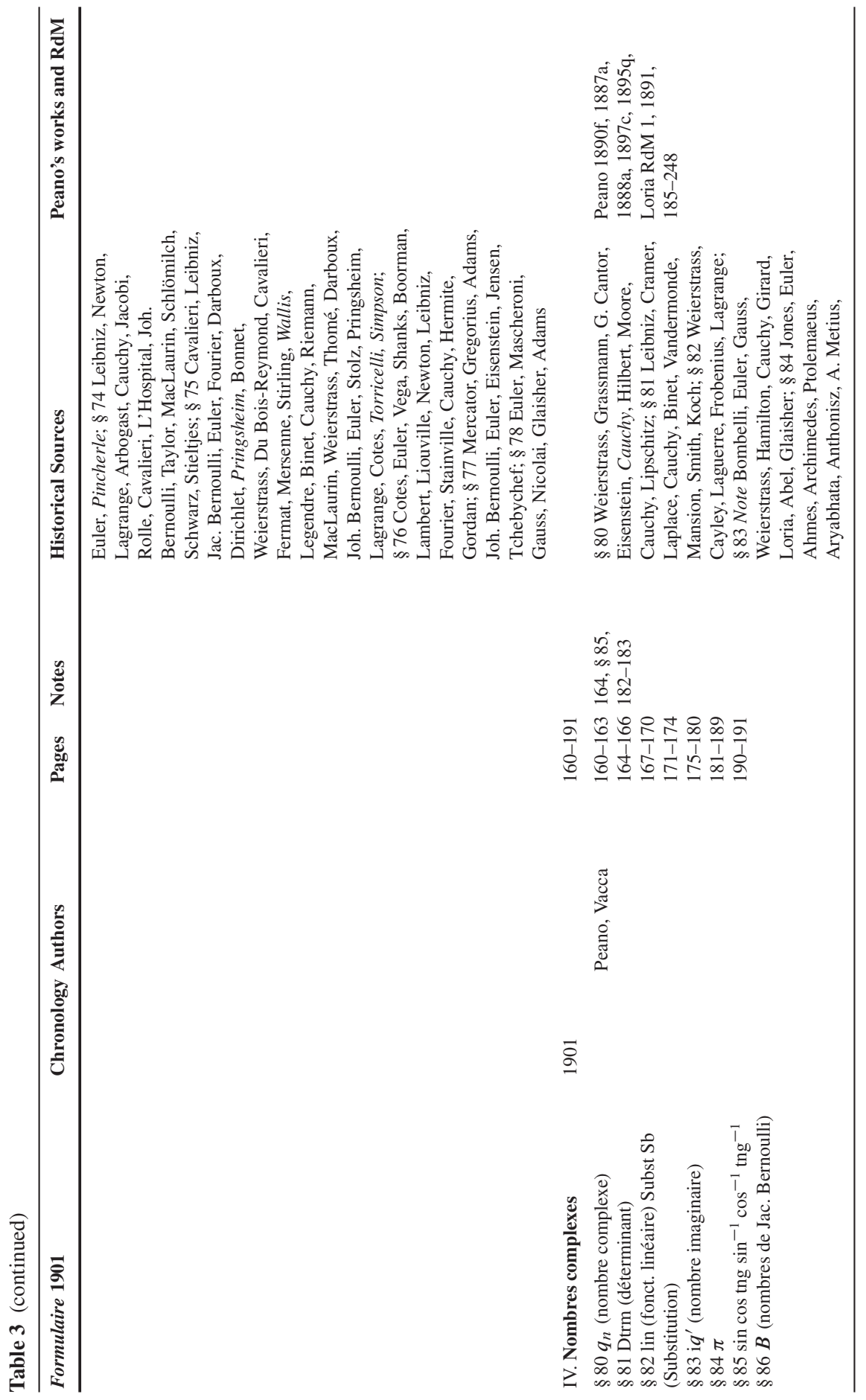




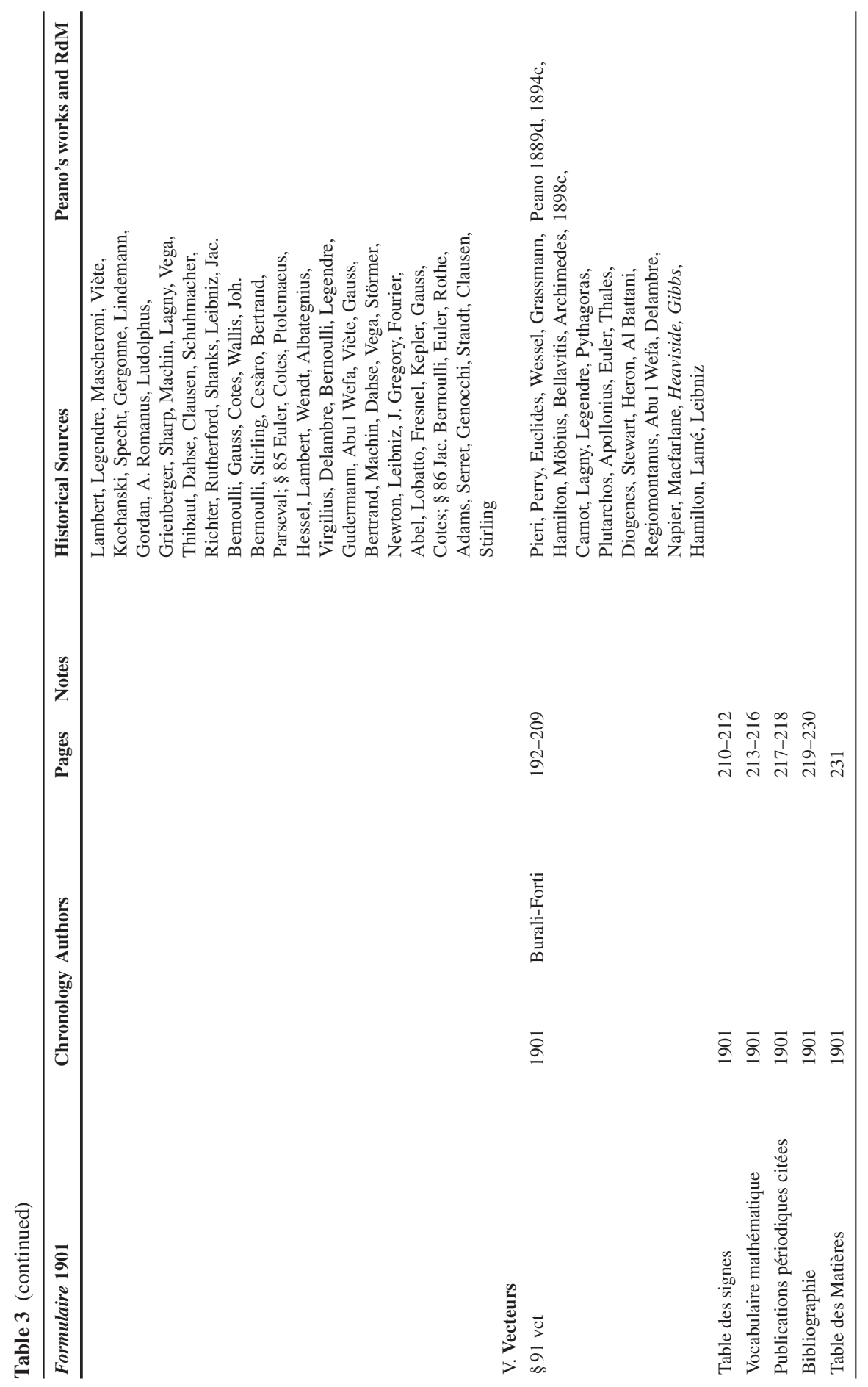




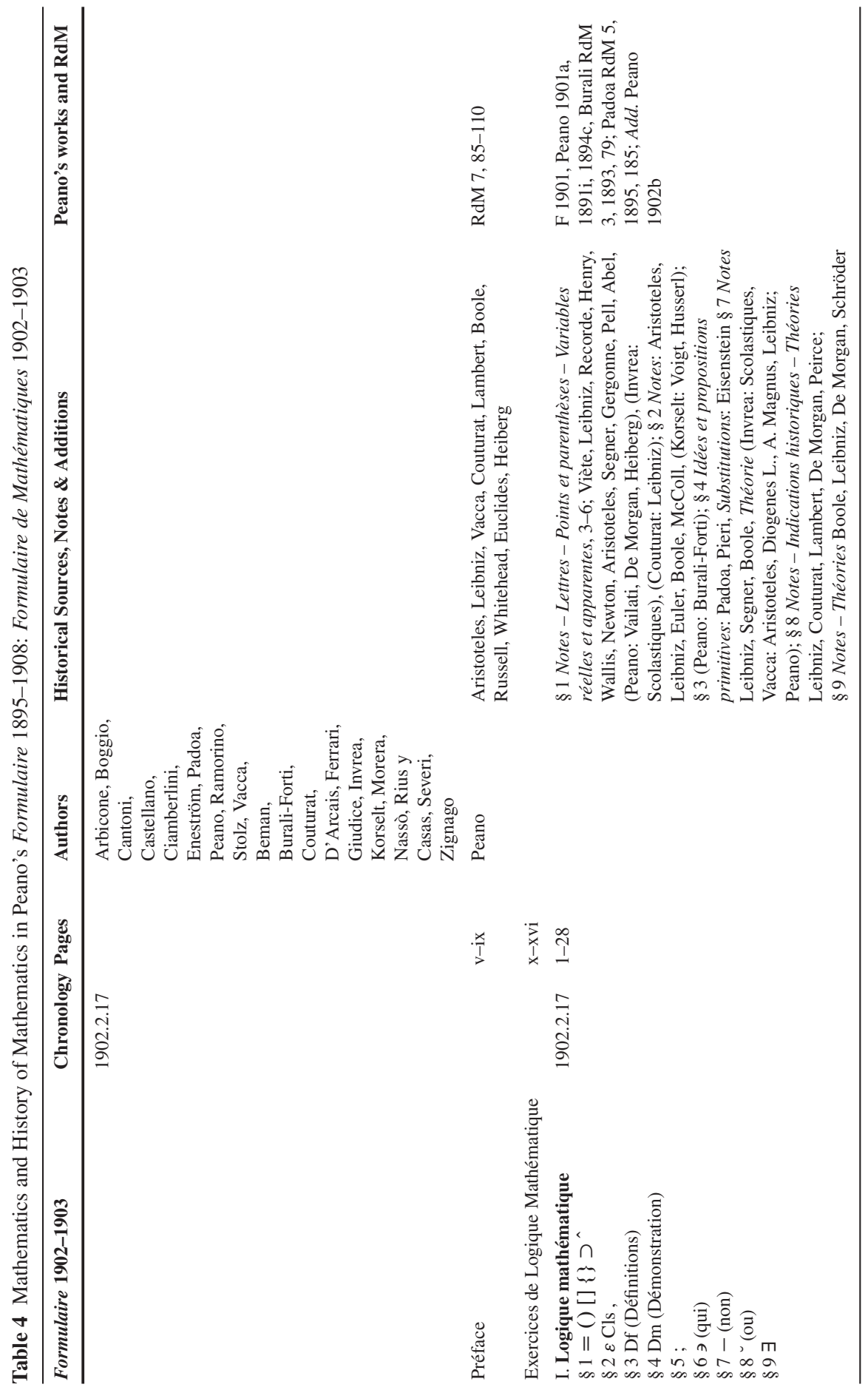




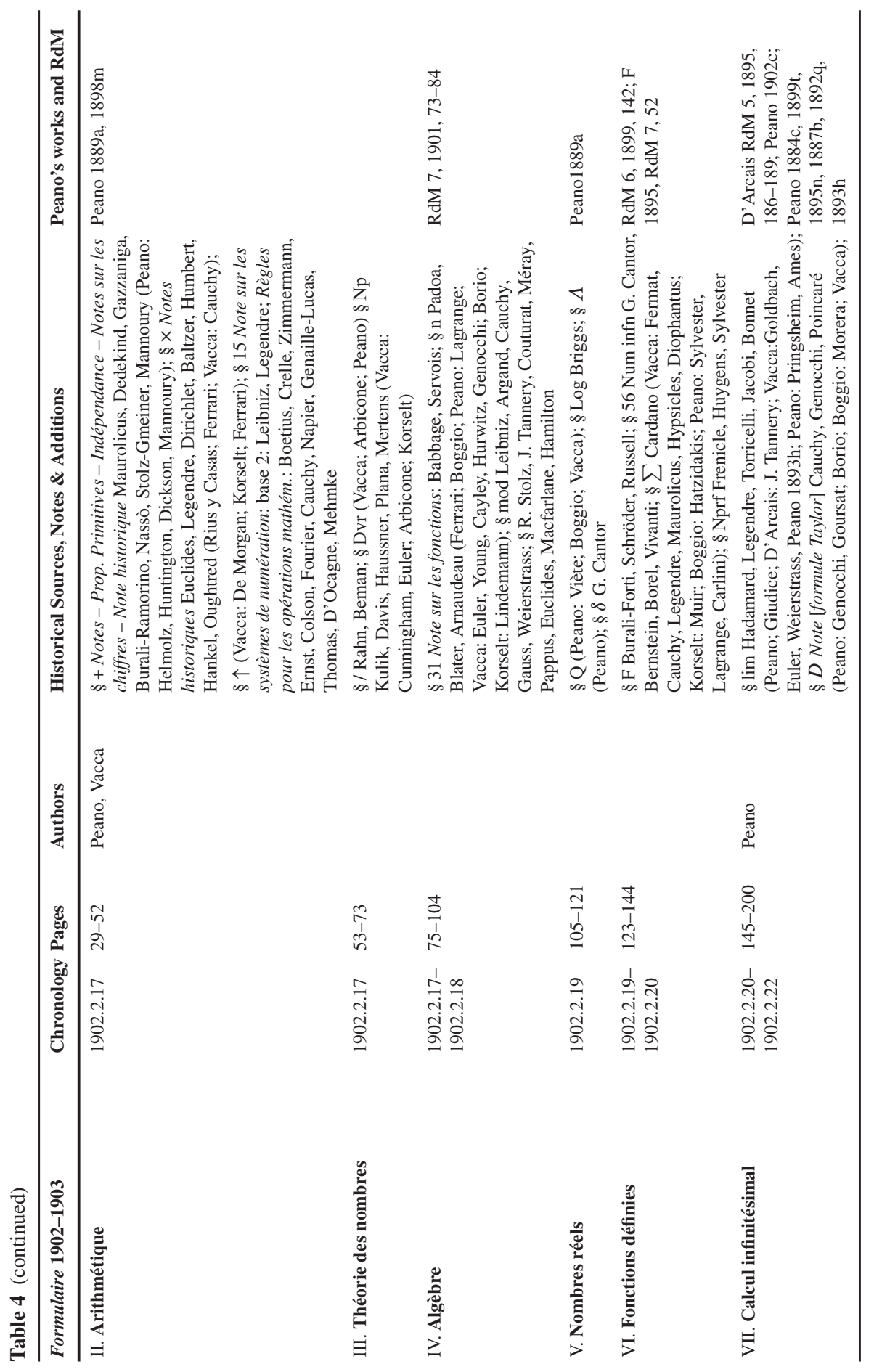




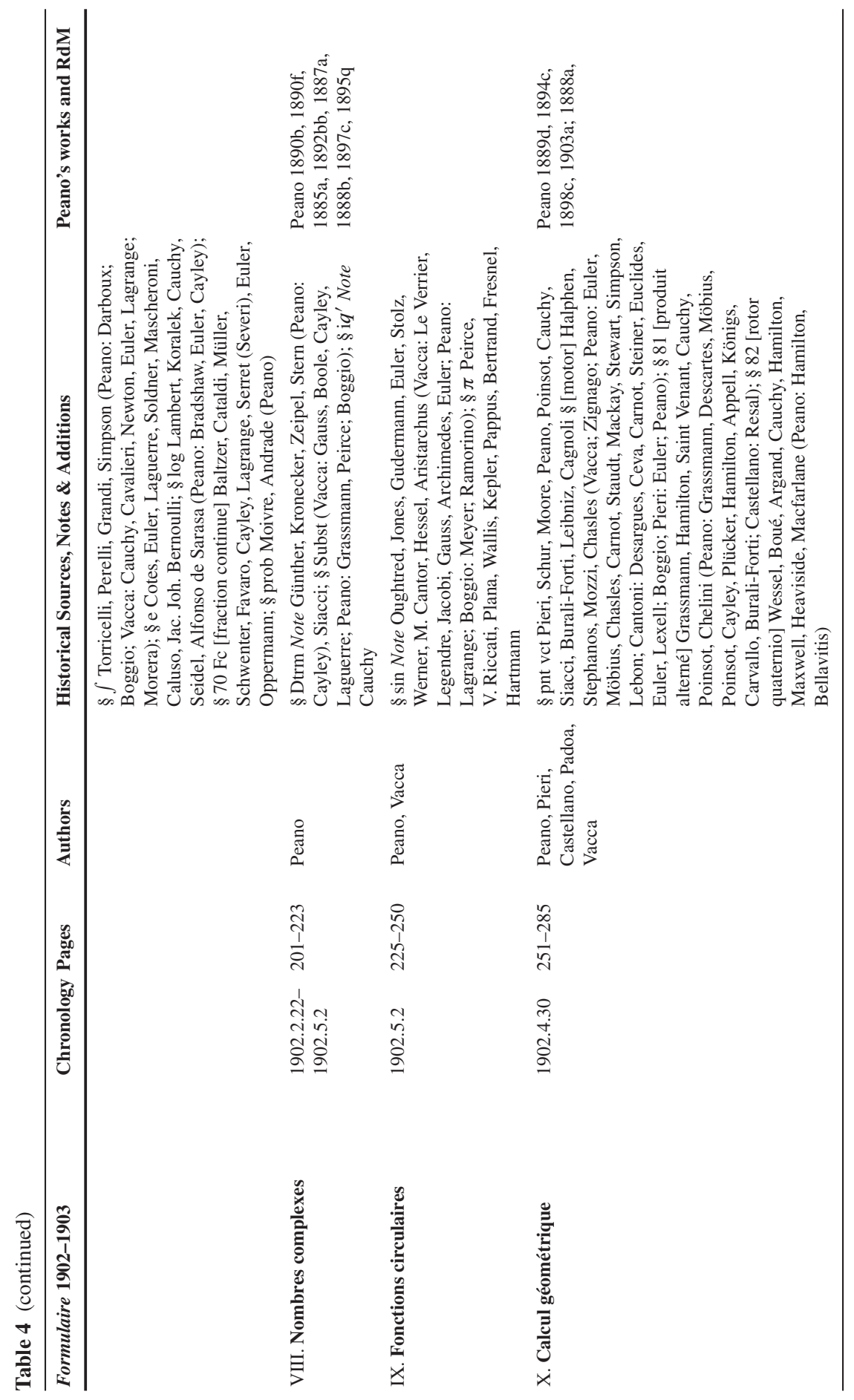




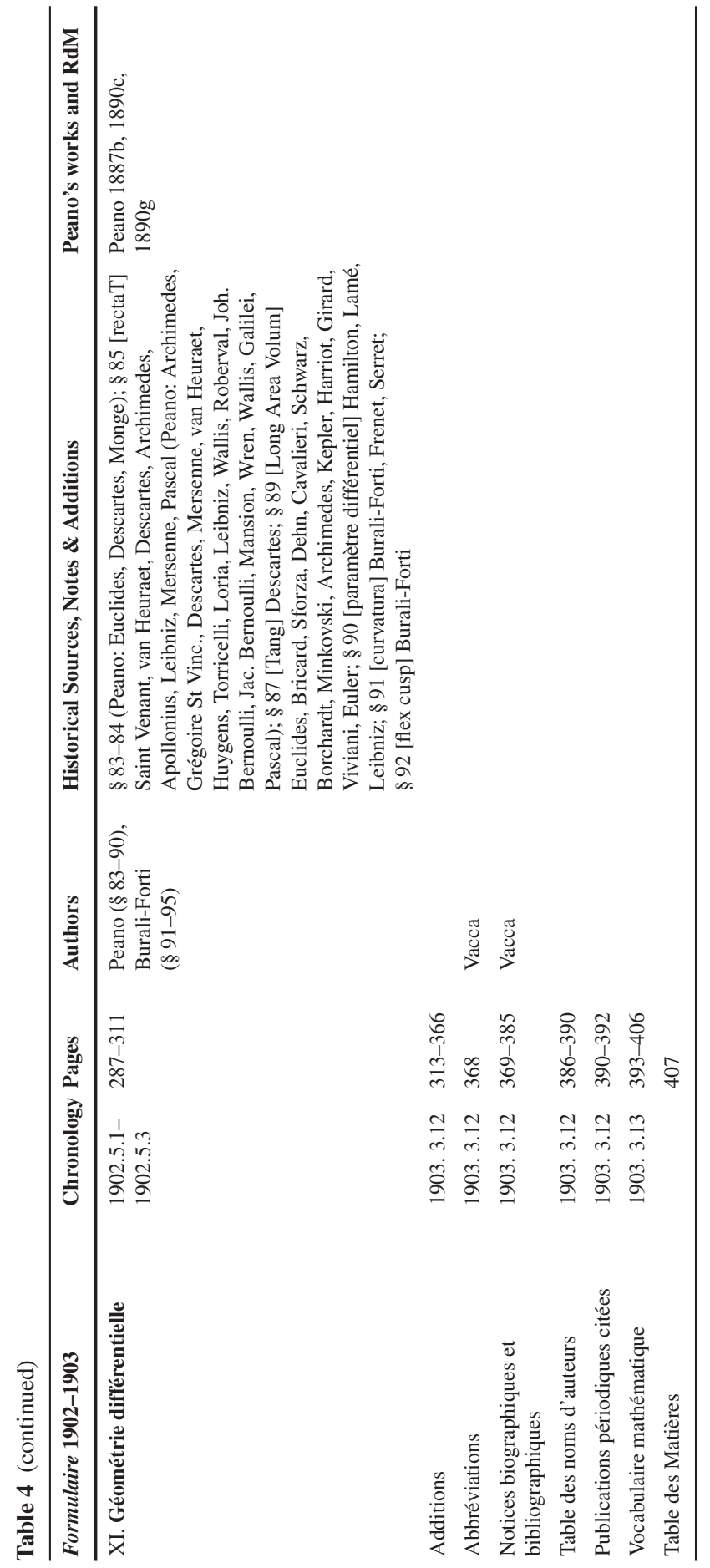




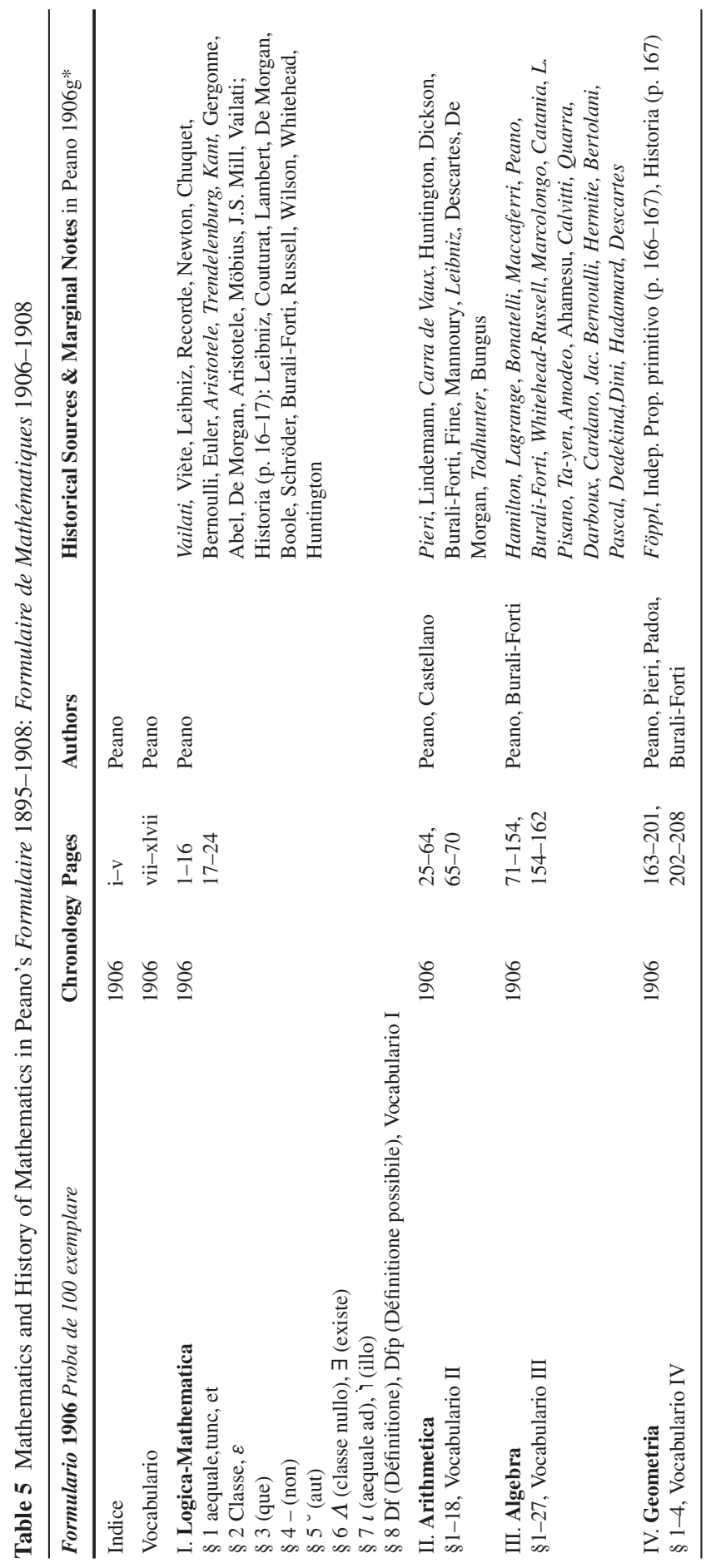




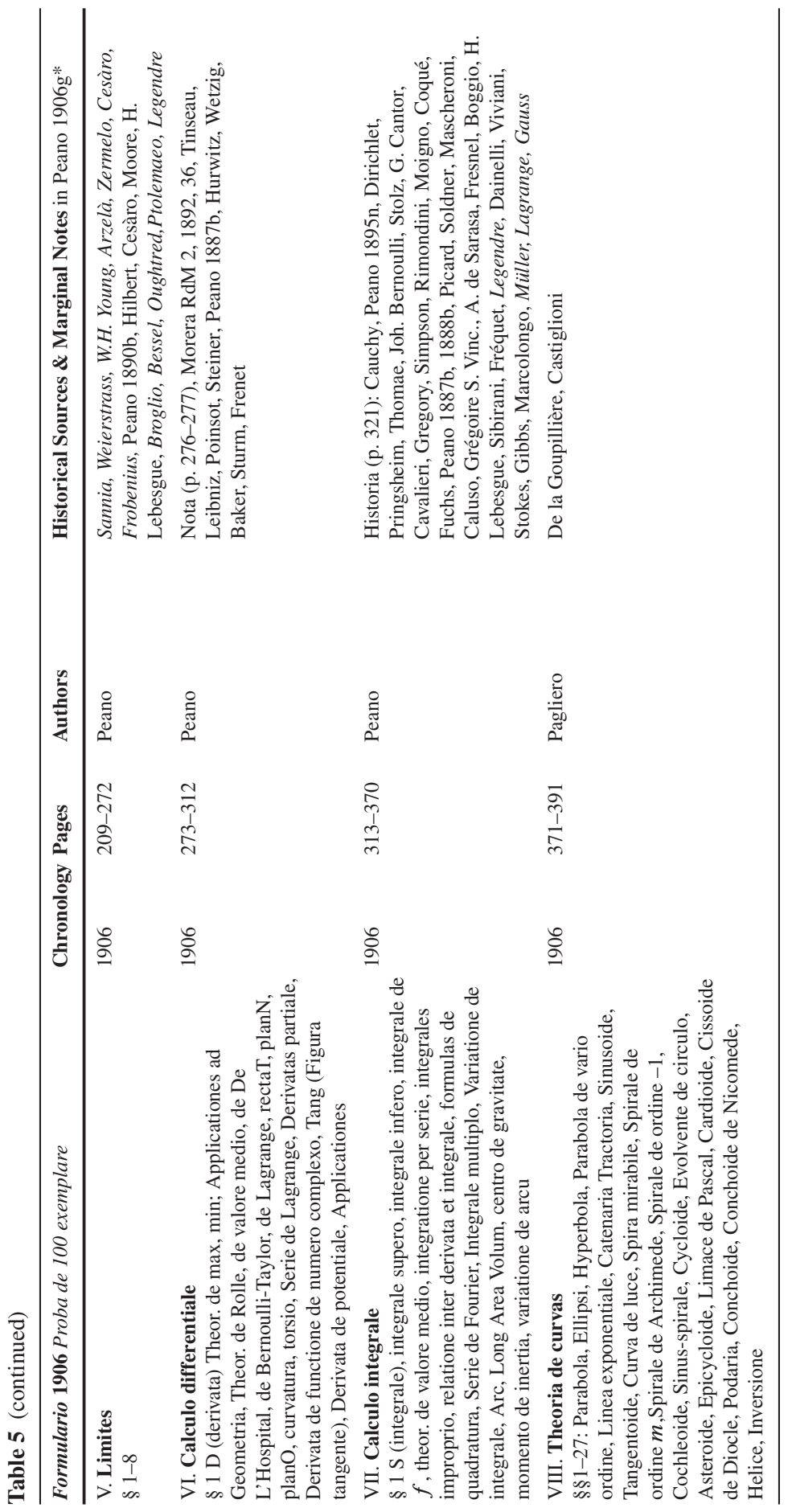




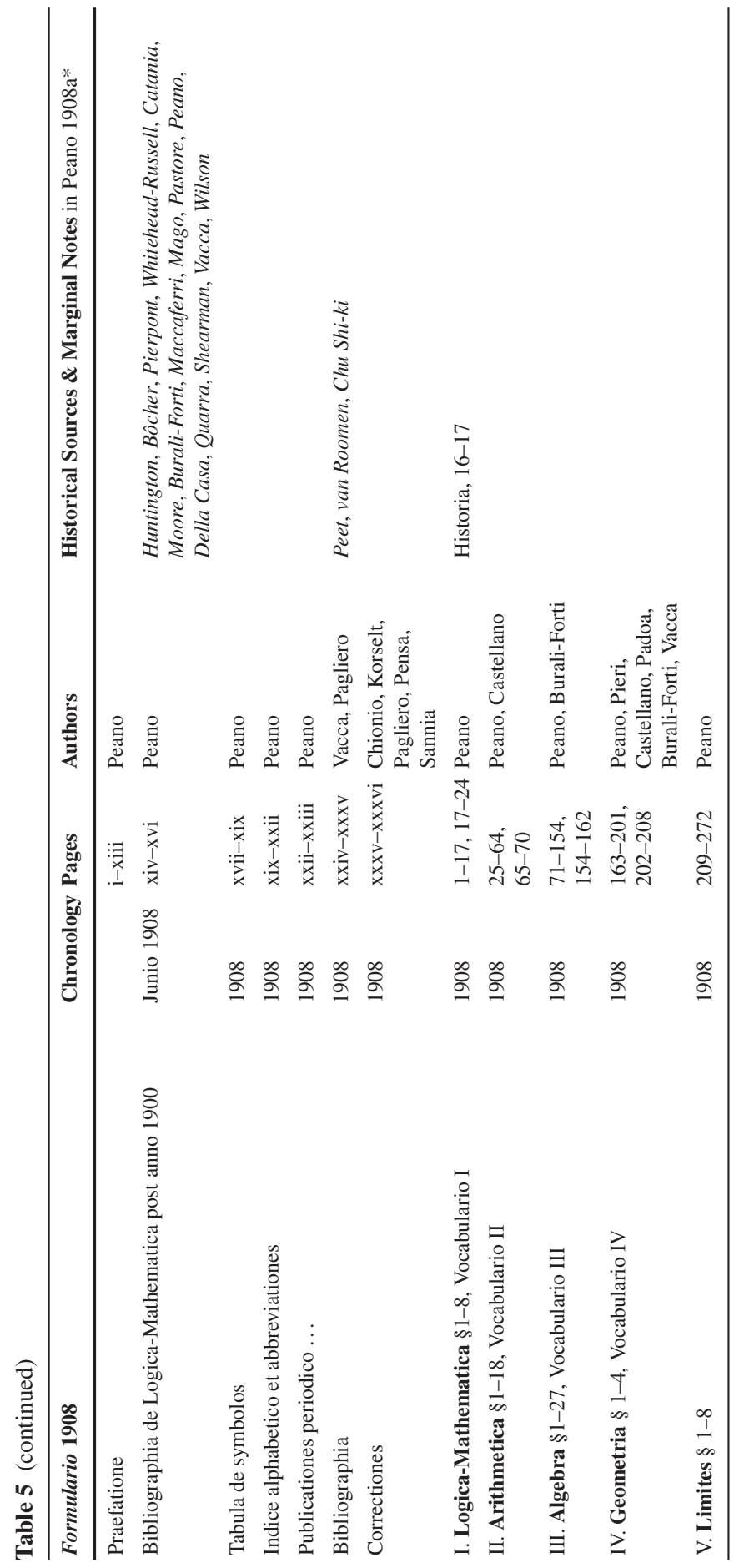




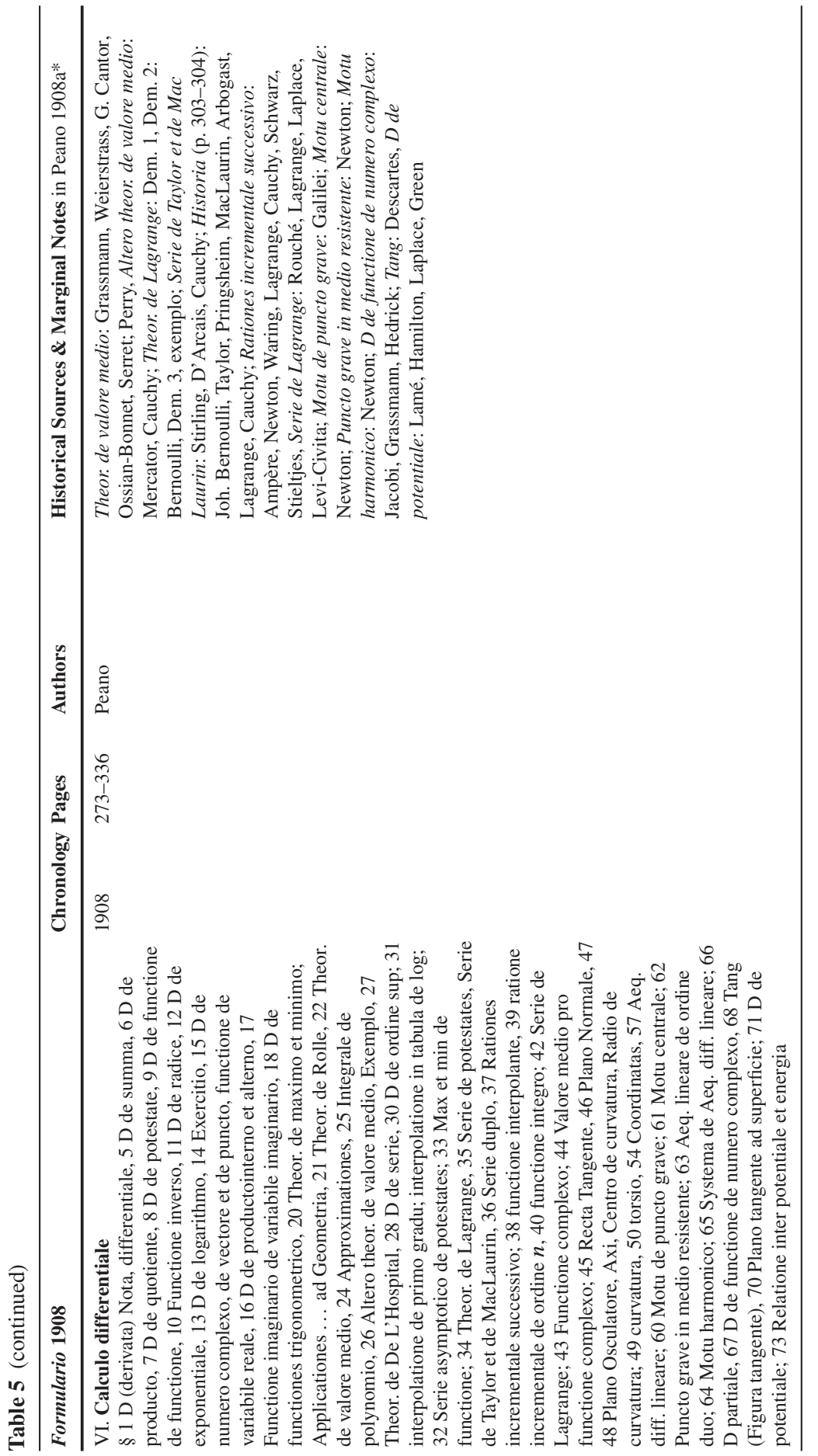




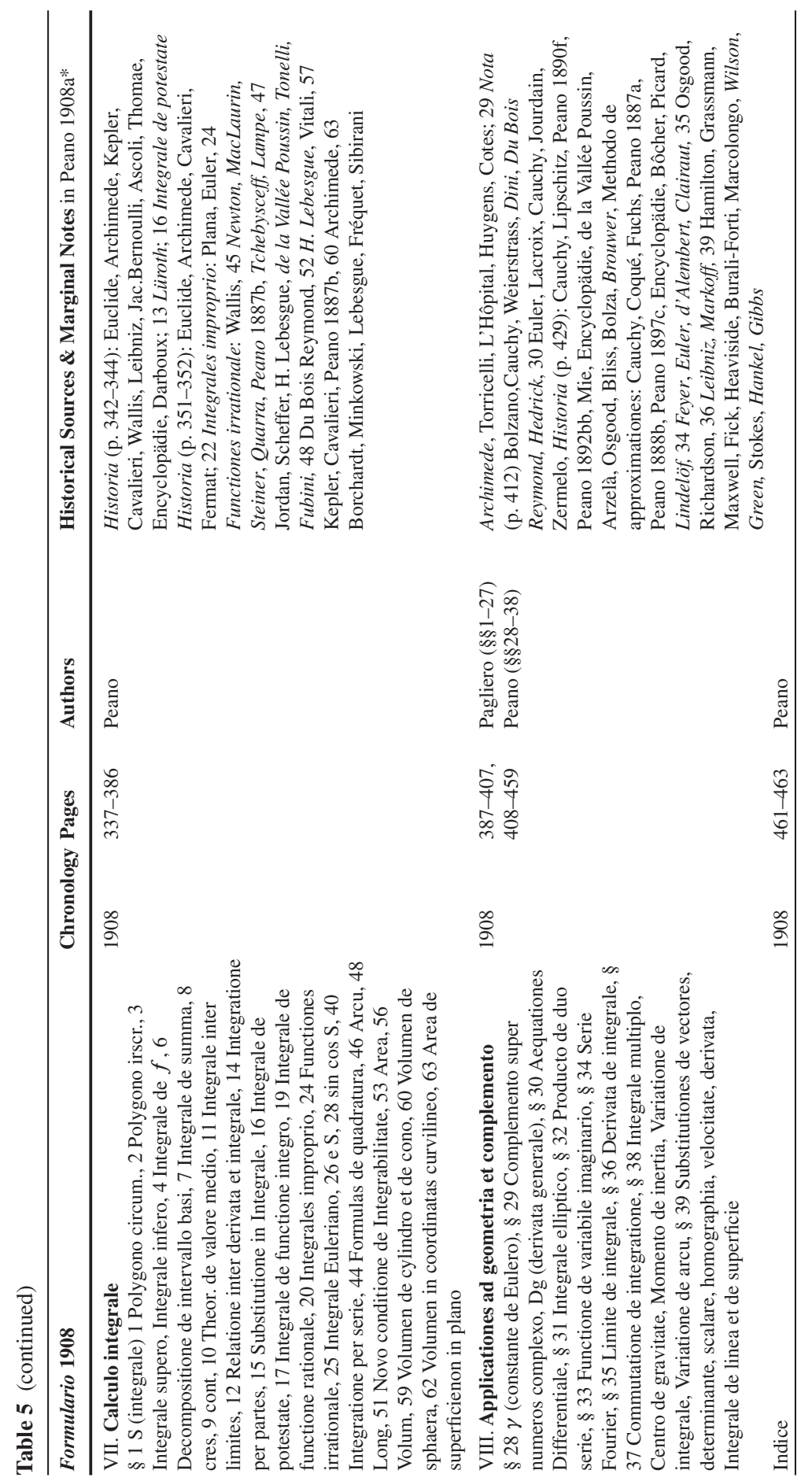




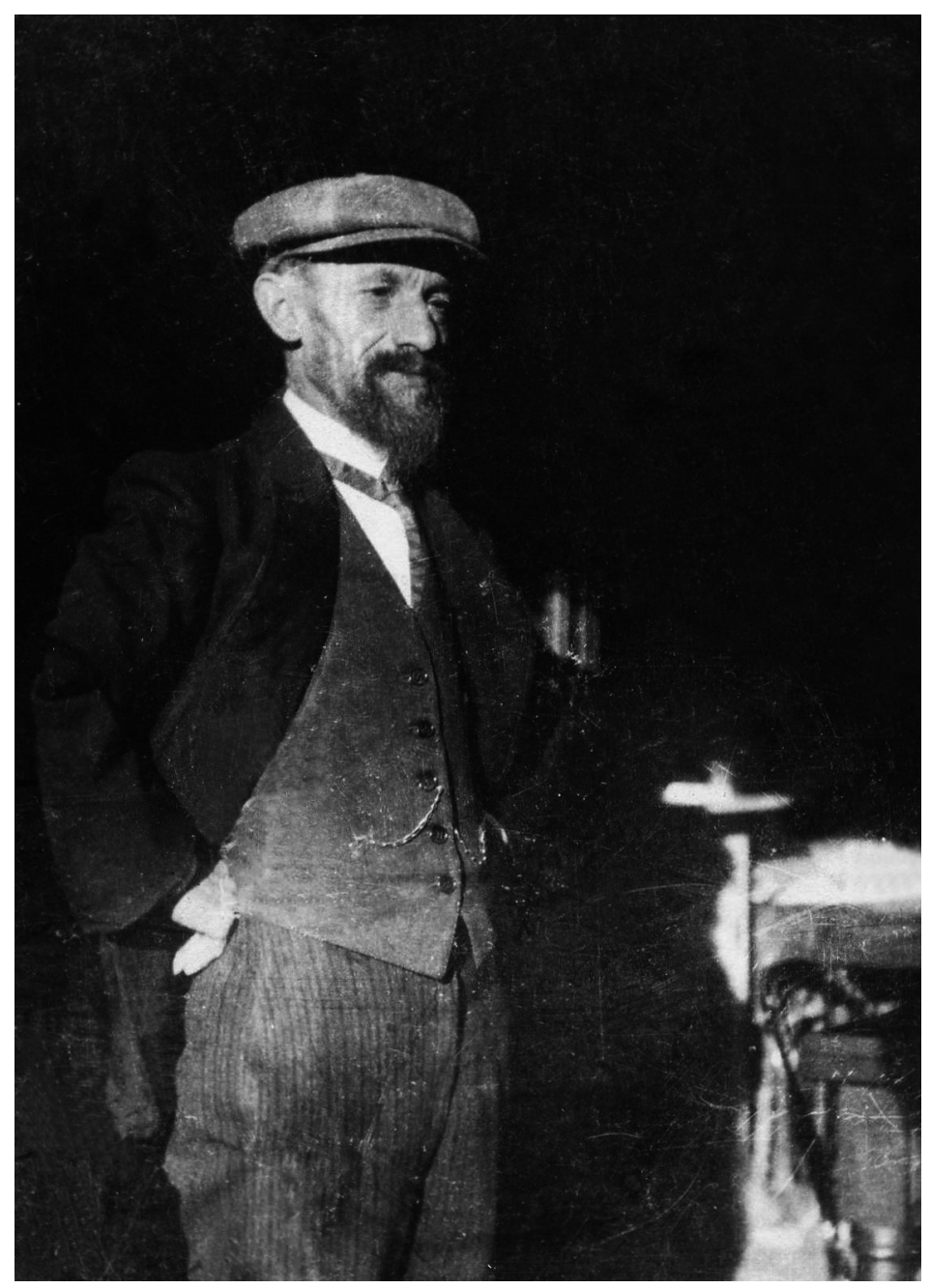

Giuseppe Peano and the printing-press in his villa in Cavoretto (Turin) - Department of Mathematics G. Peano, University of Torino 